\title{
Metal coordination with an amide-functionalized axially chiral resorcinarene
}

Jamila Vaughan, ${ }^{\mathrm{a}}$ Munna Ali Mohamed Bertata, ${ }^{\mathrm{a}, \mathrm{b}}$ Brian W. Skelton, ${ }^{\mathrm{c}}$ Mark I. Ogden, ${ }^{\mathrm{a}}$ and Mauro Mocerino $^{\mathrm{a}, *}$

${ }^{a}$ Curtin Institute for Functional Molecules and Interfaces, School of Molecular and Life Science, Curtin University, GPO Box U 1987, Western Australia 6845

${ }^{b}$ Faculty of Science, University of Sebha, Libya

c School of Molecular Sciences, University of Western Australia, Perth, Western Australia 6009, Australia.

email: m.mocerino@,curtin.edu.au

\begin{abstract}
The synthesis and characterization of an amide-functionalized axially chiral resorcinarene, $1^{4}, 3^{6}, 5^{6}, 7^{6}$-tetra-2-oxo-2-(2-hydroxyethylamino)ethoxy-1 $1^{6}, 3^{4}, 5^{4}, 7^{4}$-tetramethoxy-2,4,6,8tetrapropylresorcin[4]arene, is reported. Metal complexation with picrate salts gave crystalline products that could be structurally characterised for calcium, lanthanum, praseodymium, and ytterbium. While the details of these structures vary, the metal-ligand interactions are remarkably consistent, with coordination polymers formed through interaction between three of the amide $\mathrm{O}$ atoms, each binding to a different metal atom. No other potential donor atom of the macrocycle is bound to the metal atoms, with the coordination spheres completed by solvent or picrate donor $\mathrm{O}$ atoms.
\end{abstract}

Keywords: resorcinarene, lanthanide, picrate, crystal structure

Dedicated to Prof. Karsten Gloe on the occasion of his $70^{\text {th }}$ birthday. 


\section{Introduction}

Resorcinarenes are macrocyclic compounds derived from resorcinol subunits that have attracted a great deal of attention in supramolecular chemistry. Amongst the many different approaches to functionalise these compounds, asymmetric functionalisation with achiral moieties to produce chiral molecules ${ }^{1}$ has been of interest to our group, ${ }^{2-4}$ and others. ${ }^{5-9}$ The single step synthesis of the axially-chiral tetramethoxy derivative provided ready access to a racemic mixture (Figure 1). ${ }^{4}$ Resolution was later achieved by conversion to a tetracamphorsulfonate derivative followed by separation of the diastereomers by column chromatography, and hydrolysis to afford the enantiomerically-pure axially-chiral tetramethoxy-resorcinarene. ${ }^{7}$ Further derivatization of these products through Mannich reactions, and alkylation of the phenol $\mathrm{O}$ atoms has provided receptors useful for ligand-assisted reactions. ${ }^{5,6}$
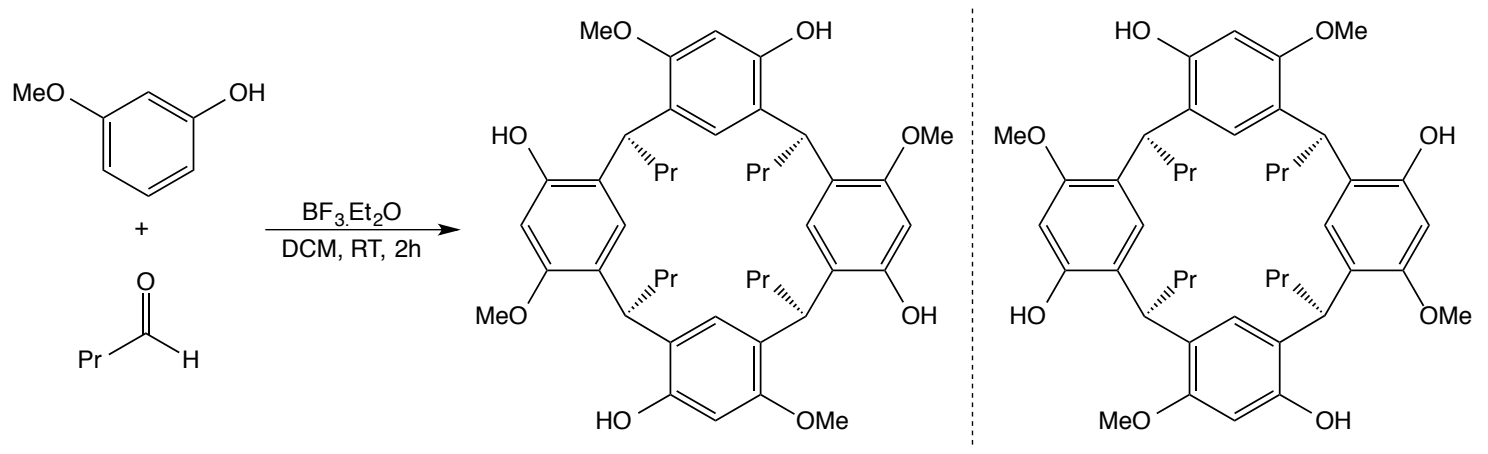

Figure 1 One-step synthesis of the axially-chiral resorcinarene, $1 .{ }^{4}$

We have previously reported the synthesis of $C 4$-symmetric pyridine-substituted resorcinarenes through direct alkylation of $\mathbf{1}$, isolated as racemic mixtures, which were investigated as potential metal-binding receptors. A copper complex was structurally characterised and found to form a linear coordination polymer. ${ }^{2}$ Yan et al., has reported the synthesis, crystal structures and complexing propertiesisêpiof tetramethoxyresorcinarene derivatives functionalized with tetraacylhydrazones.(Ref 15). The complexing properties of the ligands towards a range of transition metals and lead(II) were studies by monitoring changes in UV-Vis spectra. Crystal structures of the metal complexes were not reported. In a subsequent paper, Yan et al., reported the fluorescence sensing properties of these ligands. (Ref 16) The found that the salicylaldehyde derived Shiff bases showed efficient recognition of zinc ions with a remarkable enhancement of fluorescence intensity. We have now extended our work by functionalising the resorcinarene with an hydroxyethylamide donor group to form racemic $\mathbf{L}$ (Figure 2), with the aim of binding harder metal ions, such as Group 2, and lanthanoid cations. We report here the synthesis of $\mathbf{L}$, along with the intermediate tetraester 2 , which we have described previously as a corrosion inhibitor. ${ }^{10}$ We also 
report crystal structures of the calcium, lanthanum, praseodymium, and ytterbium complexes of $\mathbf{L}$ isolated as picrate salts.

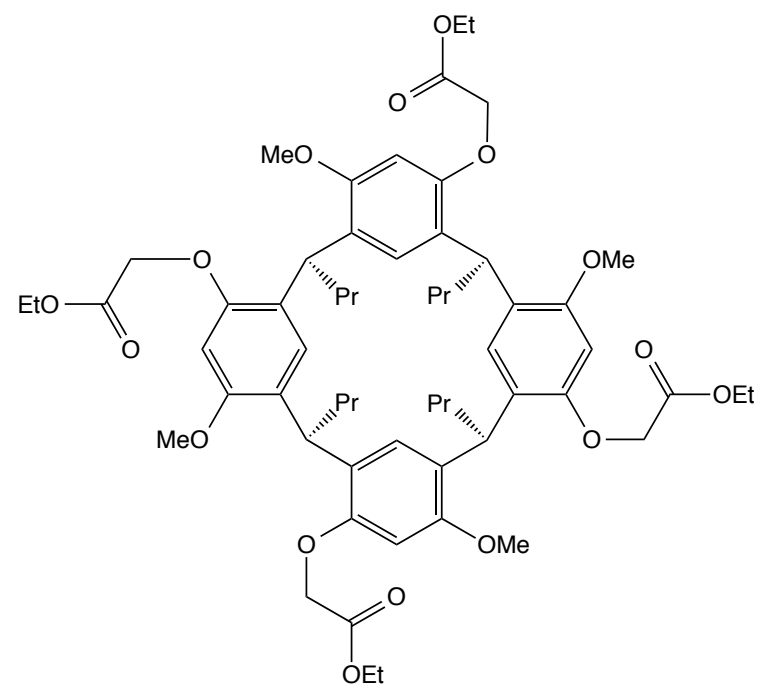

2

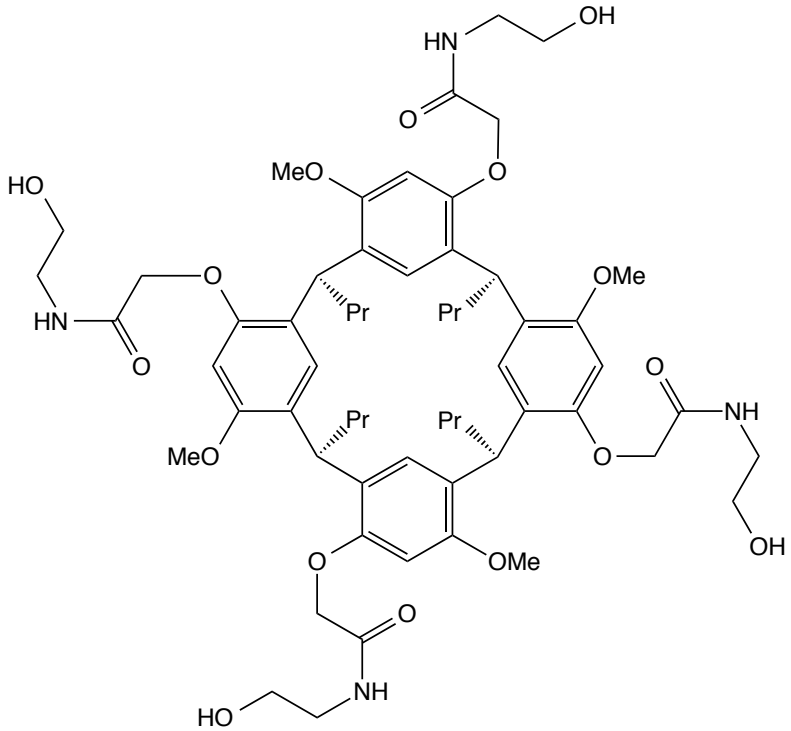

$\mathbf{L}$

Figure 2 Structures of resorcinarene ester intermediate 2 , and the target ligand, $\mathbf{L}$

\section{Experimental}

Chemical reagents and solvents were purchased from Sigma-Aldrich. Calcium picrate pentahydrate, ${ }^{11}$ lanthanoid picrate hydrates $(\mathrm{Ln}=\mathrm{La}, \mathrm{Pr}, \mathrm{Yb}),{ }^{12,13}$ and 2,4,6,8-tetrapropyl16,34,54,74-tetramethoxyresorcin[4] arene-14,36,56,76-tetrol $1,{ }^{4}$ were synthesised by literature methods. Melting points were recorded on a VWR-IA9100 instrument using open ended capillaries. Infrared spectra (IR) were collected using FTIR-ATR, on a Perkin-Elmer Spectrum TwoTM Infrared Spectrometer. Nuclear Magnetic Resonance (1H, DEPT-Q 13C, 2D COSY, 2D HSQC, 2D HMBC) spectra were obtained using a Bruker Ultrashield 400TM instrument (400 MHz) at room temperature. Chemical shifts were recorded on the $\delta$ scale relative to the deuterated solvent $\left(\mathrm{CDCl}_{3}\right.$, DMSO).

\section{Synthesis}

$1^{4}, 3^{6}, 5^{6}, 7^{6}$-tetraethoxycarbonylmethyleneoxy $-1^{6}, 3^{4}, 5^{4}, 7^{4}$-tetramethoxy-2, 4, 6, 8tetrapropylresorcin[4]arene, 2

Resorcinarene 1 (5.02 g, $7.04 \mathrm{mmol})$, ethyl bromoacetate (10.0 g, $0.06 \mathrm{~mol})$ and potassium carbonate $(15.37 \mathrm{~g}, 0.11 \mathrm{~mol})$ were dissolved in dry acetonitrile $(100 \mathrm{~mL})$ and heated at reflux overnight. The reaction mixture was then cooled, filtered and the remaining ethyl bromoacetate and acetonitrile were removed at reduced pressure yielding a white precipitate which was dissolved in 
ethyl acetate $(20 \mathrm{~mL})$ and washed with water $(2 \times 100 \mathrm{~mL})$ and brine $(1 \times 100 \mathrm{~mL})$. The organic layer was dried with magnesium sulfate and the ethyl actetate was removed under reduced pressure leaving a glass like oil which was recrystallised from ethanol yielding white crystals (4.6 g, 61\% yield, mp $\left.133{ }^{\circ} \mathrm{C}\right) .{ }^{1} \mathrm{H} \mathrm{NMR} \mathrm{CDCl}_{3} \delta 0.91\left(\mathrm{t}, J=7.2 \mathrm{~Hz}, 12 \mathrm{H}, \mathrm{CH}_{2} \mathrm{CH}_{3}\right) .1 .27(\mathrm{t}, J=7.1 \mathrm{~Hz}, 12 \mathrm{H}$, $\mathrm{OCH}_{2} \mathrm{CH}_{3}$ ), 1.30 - 1.39 (apparent q, $8 \mathrm{H}, \mathrm{CH}_{2} \mathrm{CH}_{3}$ ), 3.60 (s, 12H, $\mathrm{OCH}_{3}$ ), 3.96, 4.20. (2d, $J=15.8$ $\left.\mathrm{Hz}, 8 \mathrm{H}, \mathrm{CH}_{2} \mathrm{CO}\right), 4.21-4.26\left(\mathrm{~m}, 12 \mathrm{H}, \mathrm{CH}_{2} \mathrm{O}\right), 4.53$ (t, J=7.4 Hz, 4H, $\left.\mathrm{CHCH}_{2}\right), \delta 6.28(\mathrm{~s}, 4 \mathrm{H}, \mathrm{Ar}$ $H), 6.61(\mathrm{~s}, 4 \mathrm{H}, \mathrm{Ar} H) .{ }^{13} \mathrm{C} \mathrm{NMR}\left(\mathrm{CDCl}_{3}\right) \delta 14.22,14.30\left(2 \mathrm{CH}_{3}\right), 21.08,35.21,37.00\left(2 \mathrm{CH}_{2}\right.$ and $\mathrm{CH})$, 55.56, 60.91, $68.37\left(\mathrm{OCH}_{3}, \mathrm{OCH}_{2} \mathrm{CH}_{3}\right.$ and $\left.\mathrm{OCH}_{2} \mathrm{CO}\right), 99.56,126.27,127.47,128.20,154.92$, 155.85 (Ar), $169.6(\mathrm{C}=\mathrm{O})$. IR $1753(\mathrm{CO}), 2923\left(\mathrm{CH}_{2}\right), 2855\left(\mathrm{CH}_{3}\right), 1684(\mathrm{C}=\mathrm{C}), 1301 \mathrm{~cm}^{-1}(\mathrm{C}-\mathrm{O})$. HRMS $m / z[\mathrm{M}+\mathrm{H}]^{+}$calculated for $\mathrm{C}_{60} \mathrm{H}_{81} \mathrm{O}_{16}$ 1057.5535, found 1057.5502.

\section{$1^{4}, 3^{6}, 5^{6}, 7^{6}$-tetra-2-oxo-2-(2-hydroxyethylamino)ethoxy-1 $1^{6}, 3^{4}, 5^{4}, 7^{4}$-tetramethoxy-2, 4, 6, 8- tetrapropylresorcin[4]arene, $\mathbf{L}$}

Compound 2 (1.05 g, $0.99 \mathrm{mmol})$ was dissolved in ethanolamine $(20 \mathrm{~mL}, 0.33 \mathrm{~mol})$ and heated at reflux overnight. The reaction mixture was then acidified with $\mathrm{HCl}(200 \mathrm{~mL}, 5 \mathrm{M})$ producing a light green precipitate which was recrystallised from methanol yielding light green crystals of $\mathbf{L}(0.92 \mathrm{~g}$, $86 \%$ yield, mp $\left.222{ }^{\circ} \mathrm{C}\right) .{ }^{1} \mathrm{H}$ NMR DMSO $\delta 0.86\left(\mathrm{t}, J=7.4, \mathrm{~Hz}, 12 \mathrm{H}, \mathrm{CH}_{3} \mathrm{CH}_{2}\right), 1.15-1.89(\mathrm{~m}, 8 \mathrm{H}$, $\left.\mathrm{CH}_{2} \mathrm{CH}_{3}\right), 1.70-1.88\left(\mathrm{~m}, 8 \mathrm{H}, \mathrm{CH}_{2} \mathrm{CH}\right), 3.13-3.33\left(\mathrm{~m}, 8 \mathrm{H}, \mathrm{CH}_{2} \mathrm{~N}\right), 3.39-3.48\left(\mathrm{~m}, 8 \mathrm{H}, \mathrm{CH} \mathrm{H}_{2} \mathrm{OH}\right)$, $3.65\left(\mathrm{~s}, 12 \mathrm{H}, \mathrm{OCH}_{3}\right), 4.10,4.24$. (2d, $\left.J=14.6 \mathrm{~Hz}, 8 \mathrm{H}, \mathrm{CH}_{2} \mathrm{CO}\right), 4.48(\mathrm{t}, J=7.4 \mathrm{~Hz}, 4 \mathrm{H}, \mathrm{OH}), 4.83$ $\left(\mathrm{t}, J=5.3 \mathrm{~Hz}, 4 \mathrm{H}, \mathrm{CHCH}_{2}\right), 6.52(\mathrm{~s}, 4 \mathrm{H}, \mathrm{Ar}), 6.74(\mathrm{~s}, 4 \mathrm{H}, \mathrm{Ar}), 7.33(\mathrm{t}, J=5.7 \mathrm{~Hz}, 4 \mathrm{H}, \mathrm{NH}) .{ }^{13} \mathrm{C}$ NMR. (DMSO) $\delta 14.52\left(\mathrm{CH}_{3}\right), 21.20,34.64,37.28,\left(2 \mathrm{CH}_{2}, \mathrm{CH}\right), 41.60,56.47\left(\mathrm{CH}_{2} \mathrm{OH}, \mathrm{CH}_{2} \mathrm{~N}\right)$, 60.12, $68.31\left(\mathrm{CH}_{2} \mathrm{O}\right.$ and $\left.\mathrm{CH}_{3} \mathrm{O}\right), 98.50,125.19,125.71,126.18,154.14,155.64(\mathrm{Ar}), 168.42(\mathrm{CO})$. IR $3372 \mathrm{~cm}^{-1}(\mathrm{NH}), 1655 \mathrm{~cm}^{-1}(\mathrm{C}=\mathrm{O})$. HRMS, $[\mathrm{M}+\mathrm{H}]^{+}$calculated for $\mathrm{C}_{76} \mathrm{H}_{121} \mathrm{~N}_{8} \mathrm{O}_{12}, 1117.5884$ $\mathrm{m} / \mathrm{z}$, found, $1117.5925 \mathrm{~m} / \mathrm{z}$.

\section{Metal complexation with $\mathbf{L}$}

The required metal picrate hydrate ( $\mathrm{Ca}, \mathrm{La}, \mathrm{Pr}$, or $\mathrm{Yb}, \sim 2 \mathrm{mg}$, excess) and $\mathbf{L}$ ( $2 \mathrm{mg}, \mathrm{XX}$ mmol) were dissolved in 1:1 dichloromethane:methanol (1-2 mL). The resulting solution was filtered, and allowed to evaporate under ambient conditions resulting in the deposition of highly efflorescent orange crystals in variable yield. These were subjected to single crystal X-ray analysis.

\section{Structure Determinations}

Crystallographic data for the structures were collected at 100(2) K on an Oxford Diffraction Gemini diffractometer using Mo Ka radiation. Following multi-scan absorption (analytical, for $\operatorname{Pr} \mathbf{L}$ ) corrections, the structures were refined against $F^{2}$ with full-matrix least-squares using the program 
SHELXL-2017. ${ }^{14}$ Anisotropic displacement parameters were employed for all the non-hydrogen atoms, unless otherwise stated. $\mathrm{H}$-atoms were added at calculated positions and refined by use of a riding model with isotropic displacement parameters based on those of the parent atom, unless otherwise stated.

\section{Refinement details}

$\mathbf{L} \cdot \mathrm{MeOH}$ : The atoms of the hydroxyethylamine part $-\mathrm{NH}\left(\mathrm{CH}_{2}\right)_{2} \mathrm{OH}$ of one chain $(43 \mathrm{n})$ were found to be disordered over two sets of sites with occupancies refining to 0.626(2) and its complement for the two components. Another hydroxyl group (33n) and each of the three methanol solvent molecules were also found to be disordered over two sites with occupancies for each of their two components constrained be the same as those for the $43 \mathrm{n}$ chain on the basis of close contacts and trial refinement. The hydroxyl group on chain $13 \mathrm{n}$ was also found to be disordered over two sets of sites with occupancies constrained to be equal for the two components after trial refinement. Hydrogen atoms on the oxygen atoms of the disordered solvent methanol molecules were not located.

CaL: Some atoms of two of the chains, $13 n$ and $23 n$, were modelled as being disordered over two sets of sites. Occupancies for the two components of the atoms $13 \mathrm{n}$ were set to be the same after trial refinement found them not to be significantly different. Those for the two components of $23 \mathrm{n}$ refined to $0.752(6)$ and its complement. Geometries of the disordered atoms of $13 \mathrm{n}$ were restrained to ideal values. Hydrogen atoms on the hydroxyl groups of the disordered ligands and those on the water molecules were not located.

LaL: The terminal atom of one n-propyl chain, $31 \mathrm{n}$, and the terminal $\mathrm{C}$ and $\mathrm{O}$ atom of one long chain, 43n, were all modelled as being disordered over two positions. The site occupancies of $C(213)$ and $C(214)$ were refined to $0.655(11)$ and its complement. Those for the other disordered chain were set at 0.5 after trial refinement. Hydroxyl hydrogen atoms $\mathrm{H}(134)$ and $\mathrm{H}(334)$ were refined without restraints. Coordinated water molecule hydrogen atoms were located and refined with restrained geometries. Two solvent water molecules were assigned occupancies of 0.5 after trial refinement and refined with isotropic displacement parameters.

PrL: Some atoms of two of the long chains were modelled as being disordered over two sets of sites. The site occupancies of the two sets of atoms of chain $13 \mathrm{n}$ were set to be equal after trial refinement found them not to be significantly different. The occupancies of the two sets of atoms for chain $43 \mathrm{n}$ were refined to $0.741(2)$ and its complement. The picrate anion was also found to be disordered over two sets of sites with occupancies constrained to be the same as those for chain $43 \mathrm{n}$ on the basis of close contacts. The two solvent molecules associated with these disordered groups 
were modelled as a $\mathrm{MeOH}$ and a water molecule and were also refined with the same occupancy factors on the basis of close intermolecular contacts. Remaining solvent molecules were modelled as methanol molecules with unit occupancies set after trial refinement. Geometries of the disordered atoms were restrained to ideal values. Hydroxyl hydrogen atoms of the disordered chains and those on the coordinated and solvent water molecules were not located or easily inferred on the basis of hydrogen bonding contacts as a result of disordered donor or acceptor groups.

YbL: Some atoms of two of the long chains and one propyl chain were modelled as being disordered over two sets of sites with occupancies set to be the same for each group after trial refinement found them not to be significantly different. Solvent molecules were modelled as water or methanol molecules with occupancies set at one or 0.5 after trial refinement. Geometries and displacement parameters of the long chains and of the disordered atoms were restrained to acceptable values. The coordinated picrate was also modelled as being disordered with site occupancies constrained to 0.5 . Geometries were restrained to ideal values. Solvent water molecule and hydroxyl hydrogen atoms were located where possible according to hydrogen bonding interactions. Those hydrogen atoms on disordered oxygen atoms were not included due to several possible sites. The electron density which could not be easily modelled as solvent was effectively removed by use of the program SQUEEZE. The disordered solvent molecules were refined with isotropic displacement parameters.

Crystal and Refinement Data

$\mathbf{L} \cdot \mathrm{MeOH} M=1213.43$, colourless block, $0.37 \times 0.20 \times 0.20 \mathrm{~mm}^{3}$, triclinic, space group $P \overline{1}$ (No. 2), $a=14.4690(4), b=14.5206(4), c=17.5110(4) \AA, \alpha=107.453(2), \beta=103.827(2), \gamma=104.551(2)^{\circ}$, $V=3194.17(15) \AA^{3}, Z=2, D_{\mathrm{c}}=1.262 \mathrm{~g} \mathrm{~cm}^{-3}, \mu=0.093 \mathrm{~mm}^{-1} . F_{000}=1308,2 \theta_{\max }=65.51^{\mathrm{o}}, 67857$ reflections collected, 21645 unique $\left(R_{\text {int }}=0.0277\right)$. Final $G o o F=1.028, R 1=0.0557, w R 2=$ $0.1560, R$ indices based on 14024 reflections with $I>2 \sigma(I)\left(\right.$ refinement on $\left.F^{2}\right),|\Delta \rho|_{\max }=0.857$ e $\AA^{-3}$, 926 parameters, 18 restraints. CCDC 1843155.

CaL $M=1772.78$, orange plate, $0.20 \times 0.16 \times 0.04 \mathrm{~mm}^{3}$, triclinic, space group $P \overline{1}$ (No. 2), $a=$ 14.8360(7), $b=17.5063(9), c=18.9380(10) \AA, \alpha=112.083(5), \beta=98.124(4), \gamma=104.631(4)^{\circ}, V=$ 4254.1(4) $\AA^{3}, Z=2, D_{\mathrm{c}}=1.384 \mathrm{~g} \mathrm{~cm}^{-3}, \mu=0.169 \mathrm{~mm}^{-1} . F_{000}=1878,2 \theta_{\max }=58.39^{\circ}, 42304$ reflections collected, 19674 unique $\left(R_{\text {int }}=0.0597\right)$. Final $G o o F=0.905, R 1=0.0739, w R 2=$ $0.1788, R$ indices based on 8088 reflections with $I>2 \sigma(I)$ (refinement on $\left.F^{2}\right),|\Delta \rho|_{\max }=1.463 \mathrm{e} \AA^{-3}$, 1163 parameters, 168 restraints. CCDC 1843329.

LaL $M=2048.64$, orange plate, $0.28 \times 0.22 \times 0.06 \mathrm{~mm}^{3}$, monoclinic, space group $P 2_{1} / n$ (No. 14), $a$ $=14.3754(3), b=36.0921(5), c=18.8574(4) \AA, \beta=110.953(2)^{\circ}, V=9137.0(3) \AA^{3}, Z=4, D_{\mathrm{c}}=$ 
$1.489 \mathrm{~g} \mathrm{~cm}^{-3}, \mu=0.570 \mathrm{~mm}^{-1} . F_{000}=4248,2 \theta_{\max }=60.0^{\circ}, 115272$ reflections collected, 26605 unique $\left(R_{\text {int }}=0.0574\right)$. Final $G o o F=0.978, R 1=0.0639, w R 2=0.1758, R$ indices based on 16984 reflections with $I>2 \sigma(I)$ (refinement on $F^{2}$ ), $|\Delta \rho|_{\max }=6.391$ e $\AA^{-3}, 1274$ parameters, 44 restraints. CCDC 1843723.

PrL $M=2085.21$, orange slab, $0.35 \times 0.25 \times 0.13 \mathrm{~mm}^{3}$, triclinic, space group $P \overline{1}$ (No. 2), $a=$ 13.6762(4), $b=20.1867(5), c=20.4351(5) \AA, \alpha=110.659(2), \beta=98.306(2), \gamma=109.547(3)^{\circ}, V=$ 4749.1(2) $\AA^{3}, Z=2, D_{\mathrm{c}}=1.458 \mathrm{~g} \mathrm{~cm}^{-3}, \mu=0.612 \mathrm{~mm}^{-1} . F_{000}=2168,2 \theta_{\max }=68.99^{\circ}, 110917$ reflections collected, 37374 unique $\left(R_{\text {int }}=0.0427\right)$. Final $G o o F=0.973, R 1=0.0507, w R 2=$ $0.1285, R$ indices based on 25818 reflections with $I>2 \sigma(I)\left(\right.$ refinement on $\left.F^{2}\right),|\Delta \rho|_{\max }=1.949$ e $\AA^{-3}$, 1447 parameters, 232 restraints. CCDC 1896385.

YbL $M=2058.77$, yellow plate, $0.28 \times 0.12 \times 0.05 \mathrm{~mm}^{3}$, triclinic, space group $P \overline{1}$ (No. 2), $a=$ 14.4892(9), $b=19.7037(17), c=19.7502(16) \AA, \alpha=60.988(9), \beta=75.313(6), \gamma=70.328(7)^{\circ}, V=$ 4615.2(6) $\AA^{3}, Z=2, D_{\mathrm{c}}=1.481 \mathrm{~g} \mathrm{~cm}^{-3}, \mu=1.111 \mathrm{~mm}^{-1} . F_{000}=2124,2 \theta_{\max }=57.36^{\mathrm{o}}, 47344$ reflections collected, 20494 unique $\left(R_{\text {int }}=0.0811\right)$. Final $G o o F=0.941, R 1=0.0877, w R 2=$ $0.1995, R$ indices based on 9360 reflections with $I>2 \sigma(I)$ (refinement on $\left.F^{2}\right),|\Delta \rho|_{\max }=2.570 \mathrm{e} \AA^{-3}$, 1356 parameters, 485 restraints. CCDC 1896384.

\section{Supplementary material}

Full details of the structure determinations have been deposited with the Cambridge Crystallographic Data Centre as CCDC 1843155, 1843329, 1843723, 1896384, 1896385. These data can be obtained free of charge via http://www.ccdc.cam.ac.uk/conts/retrieving.html, or from the Cambridge Crystallographic Data Centre, 12 Union Road, Cambridge CB2 1EZ, UK; fax: (+44) 1223-336-033; or e-mail: deposit@ccdc.cam.ac.uk.

\section{Results and Discussion}

\section{Ligand Synthesis and Characterisation}

The ligand $\mathbf{L}$, was synthesized in two steps from resorcinarene $\mathbf{1}$ using modifications of established methods. Alkylation of $\mathbf{1}$ with ethyl bromoacetate using the procedure described by Buckley et al. ${ }^{6}$ gave the required tetraester $\mathbf{2}$ in moderate yield. In addition to the standard characterisation techniques, a single crystal structure determination of this compound was carried out (see Supplementary Information). Aminolysis of tetraester was achieved by heating $\mathbf{2}$ in excess ethanolamine at reflux. This gave the required hydroxamide in moderate yield as a crystalline solid. 
Yan's group has reported a similar aminolysis reaction of the methyl esters derivatives using hydrazine ${ }^{15}$ and ethylenediamine ${ }^{16}$ and also reported crystal structures of the resulting ligands.

In a number of cases, the ligand crystallised in the presence of metal salts forming crystals appropriate for single crystal X-ray structure determination. These were found to be a methanol solvate $(\mathbf{L} \cdot \mathrm{MeOH})$ in one case, and a hydrate $\left(\mathbf{L} \cdot \mathrm{H}_{2} \mathrm{O}\right)$ in another, although there was no deliberate change in the experimental procedure. It is assumed variations in the evaporation rate and specific concentrations influence the crystallization process. Neither of these structures were of sufficient quality to locate all of the protons, and the macrocycle structure is similar in both, hence only $\mathbf{L} \cdot \mathrm{MeOH}$ is discussed here. The data for $\mathbf{L} \cdot \mathrm{H}_{2} \mathrm{O}$ are given in the Supplementary Information.

Results of the structure determination confirmed the structure of $\mathbf{L}$, with the compound crystallising with three methanol solvent molecules. The molecular structure is shown in Figure 3, with the macrocycle assuming the commonly observed "boat" conformation. ${ }^{17}$ The angles between the pseudo 2-fold axis and the planes of each of the $\mathrm{Ph}$ rings are 81.73(4), 82.34(4) ${ }^{\circ}(1 \mathrm{n}$ and $3 \mathrm{n}$ ) and $3.23(4), 4.76(4)^{\circ}(2 \mathrm{n}$ and $4 \mathrm{n})$. The angle between opposite 'vertical' pairs is $15.94(5)$ ( $1 \mathrm{n}$ and $\left.3 \mathrm{n}\right)$ and $2.96(5)^{\circ}(2 \mathrm{n}$ and $4 \mathrm{n})$ between the 'horizontal' pairs.

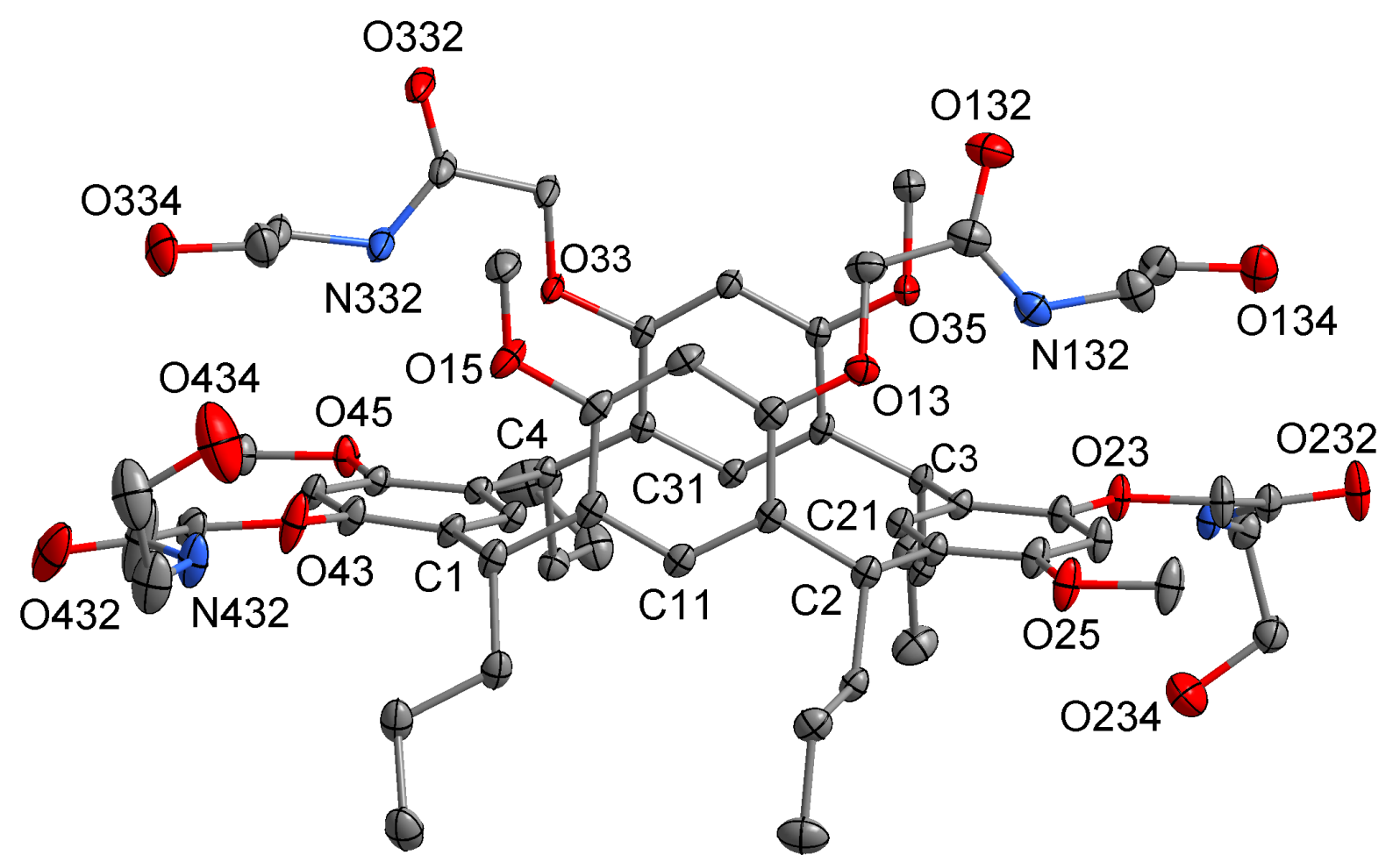

Figure 3 Molecular structure of $\mathbf{L} \cdot \mathrm{MeOH}$ projected obliquely to the plane of the four $\mathrm{CH}$ groups. Only the atoms of one or major component of the disordered components are shown. Ellipsoids have been drawn at the $50 \%$ probability level. 


\section{Metal Complexes}

Metal complexation was examined by adding metal picrate salts in excess to a

dichloromethane/methanol solution of $\mathbf{L}$. The nature of the crystals deposited appeared to be somewhat variable, presumably as a result of differing rates of evaporation, and possibly similar solubilities of the ligand and metal complex. This resulted in the crystallization of free ligand in some cases, as mentioned above. Nevertheless, it proved possible to obtain good quality crystals in a number of cases, where the yellow picrate anion provided a simple indication that the metal was likely to be present in the material.

\section{CaL}

The results of the structure determination of the calcium complex were consistent with a formulation of $\left\{\left[\mathrm{CaL}\left(\mathrm{OH}_{2}\right)(\mathrm{HOMe})(\text { pic })\right](\text { pic }) \cdot 2 \mathrm{H}_{2} \mathrm{O} \cdot 3 \mathrm{CH}_{3} \mathrm{OH}\right\}_{n}$. The complex forms a onedimensional polymer where one picrate anion is coordinated to the $\mathrm{Ca}$ atom and the second picrate is not co-ordinated. The $\mathrm{Ca}$ is bonded to the oxygen atom of one of the amide chains and also two other amide groups of two symmetry-related molecules, one related by an inversion centre and another related by cell translations in the $a b$ direction. The coordination sphere consists of the three amide oxygen atoms, the oxygen bound picrate anion, one water molecule and one $\mathrm{MeOH}$ (Figure 4). The polymer is shown in Figure 5.

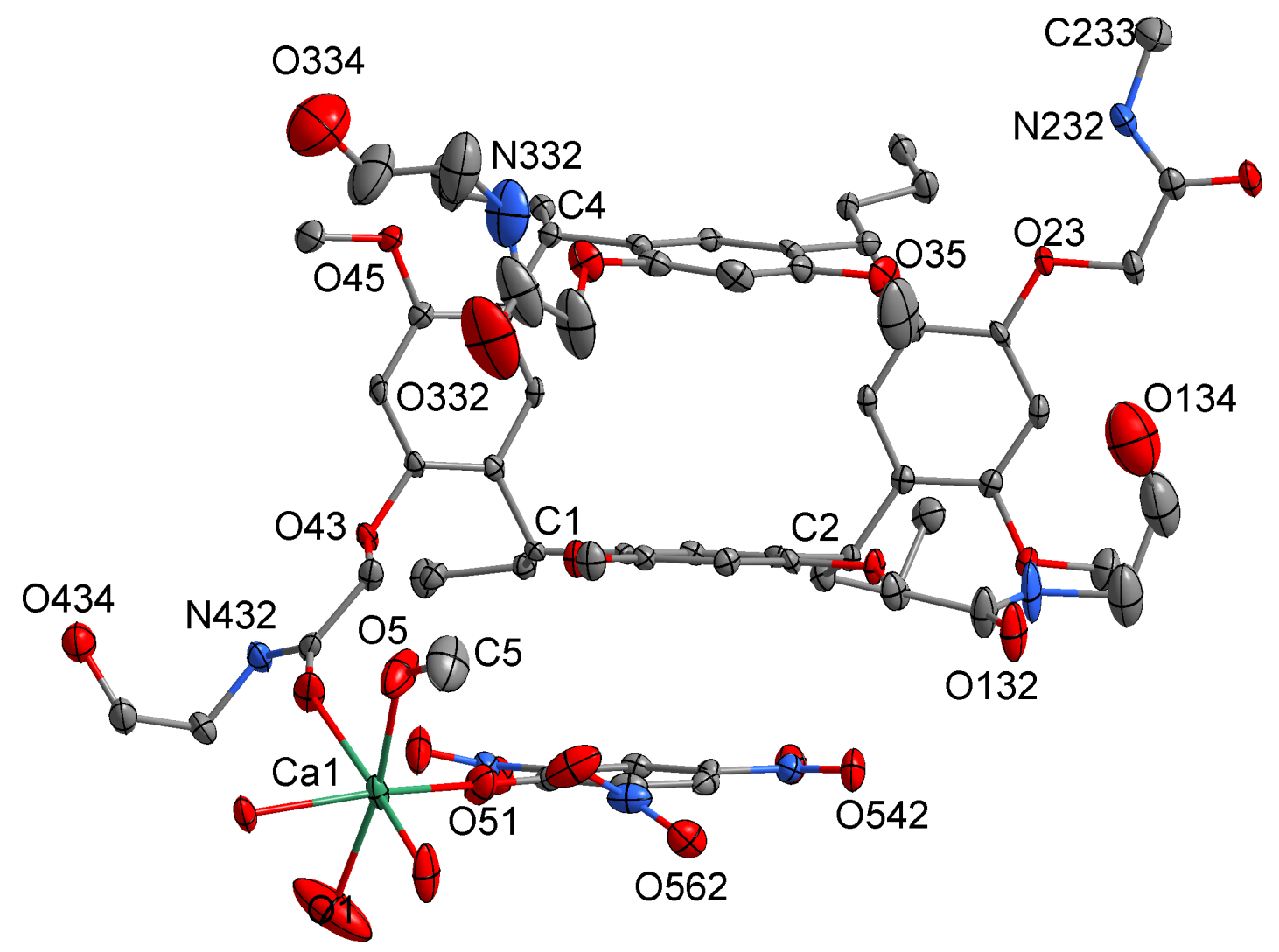

Figure 4 Molecular structure of CaL. The minor components of the disordered atoms and $\mathrm{H}$ atoms have been omitted. Ellipsoids have been drawn at the $50 \%$ probability level. 


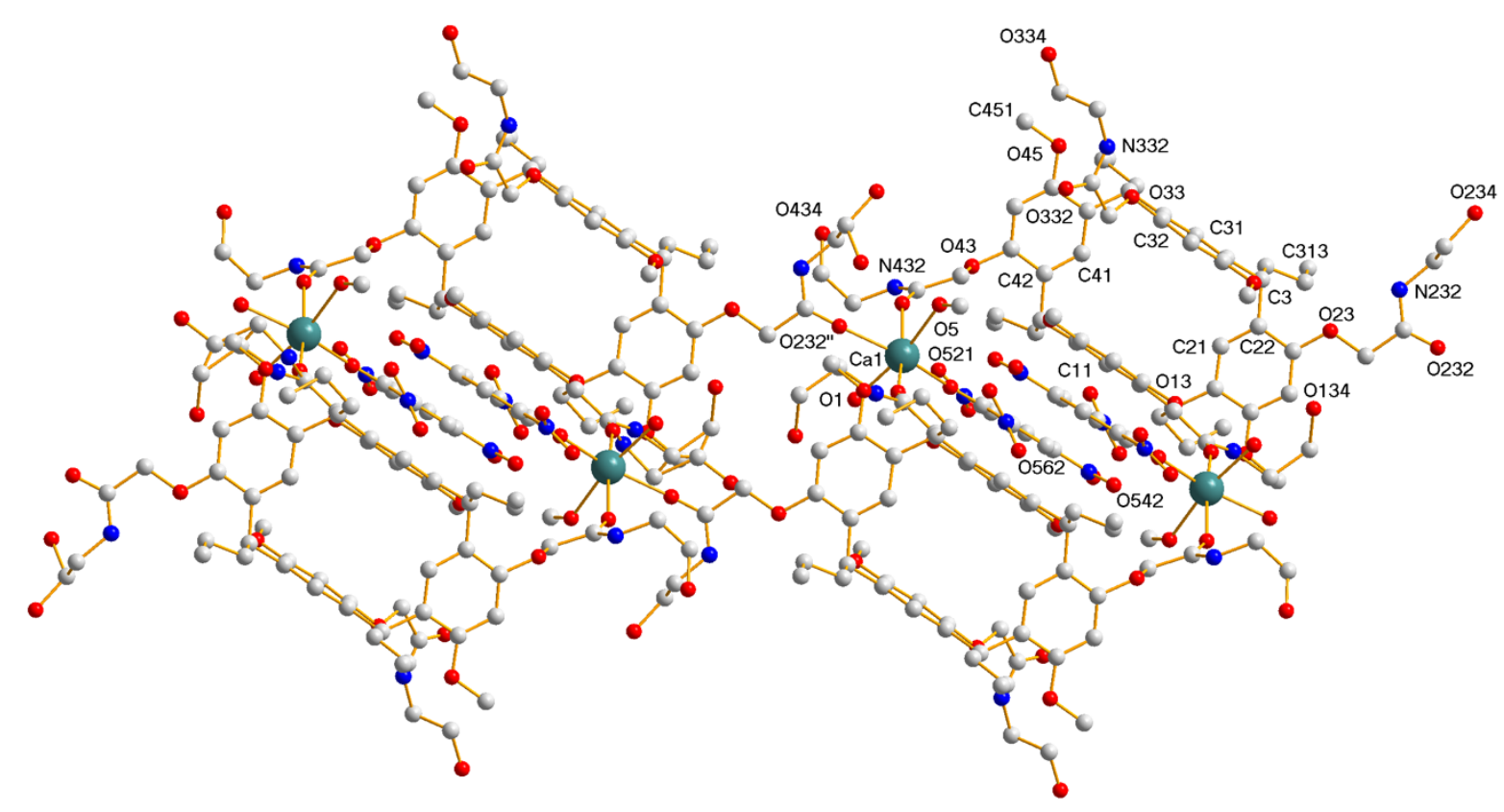

Figure 5 The one-dimensional coordination polymer formed by $\mathrm{CaL}$

The angles between the pseudo 2-fold axis and the planes of each of the $\mathrm{Ph}$ rings are 85.5(1), 85.2(1) $(1 \mathrm{n}$ and $3 \mathrm{n})$ and $11.6(1), 14.2(1)^{\circ}(2 \mathrm{n}$ and $4 \mathrm{n})$. The angle between opposite 'vertical' pairs is 9.4(1) ( $1 \mathrm{n}$ and $3 \mathrm{n})$ and $25.5(1)^{\circ}(2 \mathrm{n}$ and $4 \mathrm{n})$ between the 'horizontal' pairs.

There appears to be some interactions between the $\mathrm{Ph}$ ring (1n) and one of the coordinated picrate anions $(5 \mathrm{n})$. The angle between the two rings is $4.0(1)^{\circ}$ with the closest intra-molecular distances being $\mathrm{C}(12) \ldots \mathrm{N}(54) 3.444(4), C(13) \ldots \mathrm{N}(54) 3.404(4) \AA$. The dihedral angle between the two picrate rings is $15.6(1)^{\circ}$ with the closest approaches being $\mathrm{C}(52) \ldots \mathrm{O}(621) 3.464(4)$, $\mathrm{C}(53) \ldots \mathrm{C}(62) 3.351(5)$, and $\mathrm{C}(54) \ldots \mathrm{C}(62) 3.468(5) \AA$.

Although hydrogen atoms on the water molecules and on the hydroxyl groups of the disordered chains were not located, others can be seen to form intra-and inter-molecular hydrogen bonds. The amide hydrogen atom (H132, H135) forms an intra-molecular H-bond to the methoxy oxygen atom on the neighbouring phenyl ring, with two of the others, $H(232)$ and $H(332)$, interacting with an oxygen of a nitro-group and the phenolic oxygen of the uncoordinated picrate anion. Of the two hydrogen atoms that were located on the ligand hydroxyl groups, one $\mathrm{H}(334)$, hydrogen bonds to the coordinated water molecule of the molecule related by a symmetry translation in the $b$ direction thus linking the polymers. The other, H(434), bonds to an oxygen of another nitro group of the uncoordinated picrate anion. The hydroxyl hydrogen atoms of the $\mathrm{MeOH}$ molecules form H-bonds to either an uncoordinated water molecule $(\mathrm{O}(5)-\mathrm{H}(5) \ldots \mathrm{O}(3))$, the uncoordinated picrate anion $(\mathrm{O}(6)-\mathrm{H}(6) \ldots \mathrm{O}(61), \mathrm{O}(6)-\mathrm{H}(6) \ldots \mathrm{O}(621))$ or a ligand hydroxyl oxygen $(\mathrm{O}(7)-\mathrm{H}(7) \ldots \mathrm{O}(434))$. Details of the hydrogen bonded geometries are tabulated in the SI. 


\section{LaL}

The results of the structure determination of the lanthanum complex were consistent with the formulation $\left\{\left[\mathrm{LaL}\left(\mathrm{OH}_{2}\right)_{4} \text { (pic) }\right](\text { pic })_{2} \cdot 2 \mathrm{H}_{2} \mathrm{O}\right\}_{n}$. The structure is similar to the $\mathbf{C a} \mathbf{L}$ complex in terms of the metal-L interactions, except that it is a two-dimensional polymer (Figure 6, Figure 7). Again only one of the picrate anions is coordinated to the La atom, with the remaining two picrates not coordinated. The coordination around the La consists of four water molecules, one picrate anion bound through both the phenolic oxygen atom and a nitro group oxygen atom, and three ligand carbonyl groups, one from the ligand in the asymmetric unit, one from a ligand generated by a crystallographic $2{ }_{1}$ screw axis, and the third carbonyl from a ligand translated by one cell dimension in the $c$ direction. Hence, the metal is now nine coordinated, with the coordination geometry is best described as a capped square antiprism as shown in Figure 8 where it is projected down the pseudo 4-axis.

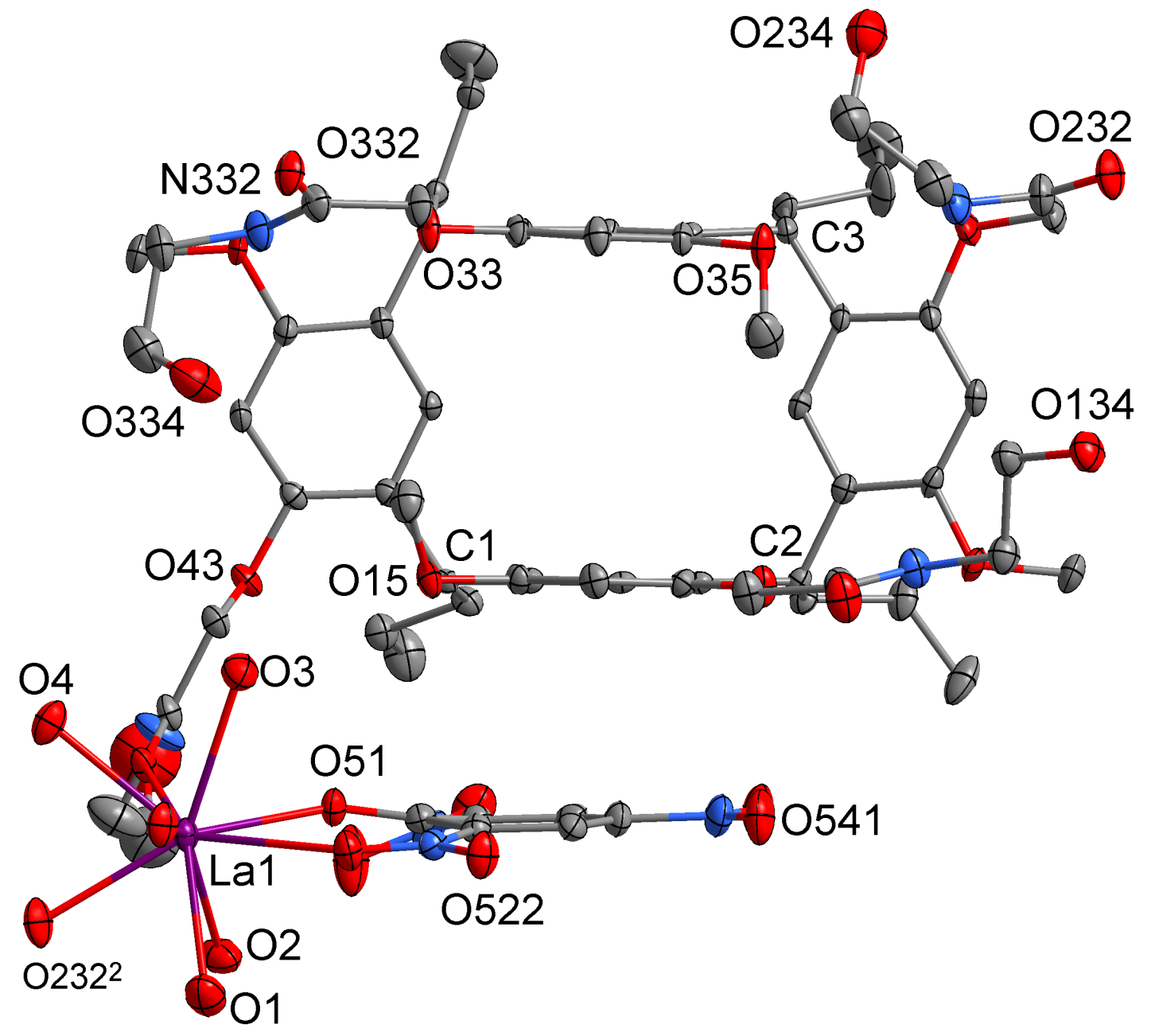

Figure 6 Molecular structure of LaL . Hydrogen atoms and the minor components of the disordered atoms have been omitted. Ellipsoids have been drawn at the $50 \%$ probability level. 


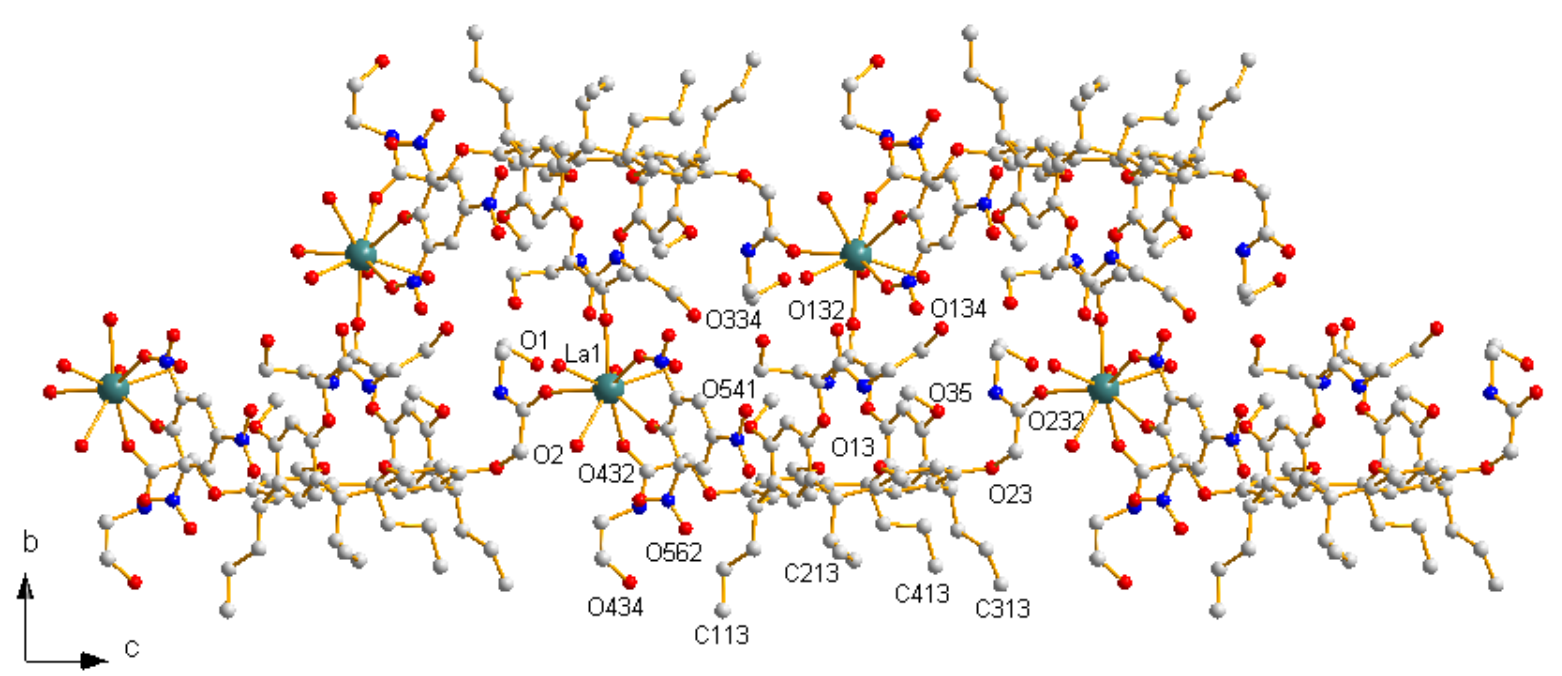

Figure 7 The structure of LaL projected along the a axis showing its polymeric nature. Hydrogen atoms and the minor components of the disordered atoms have been omitted.

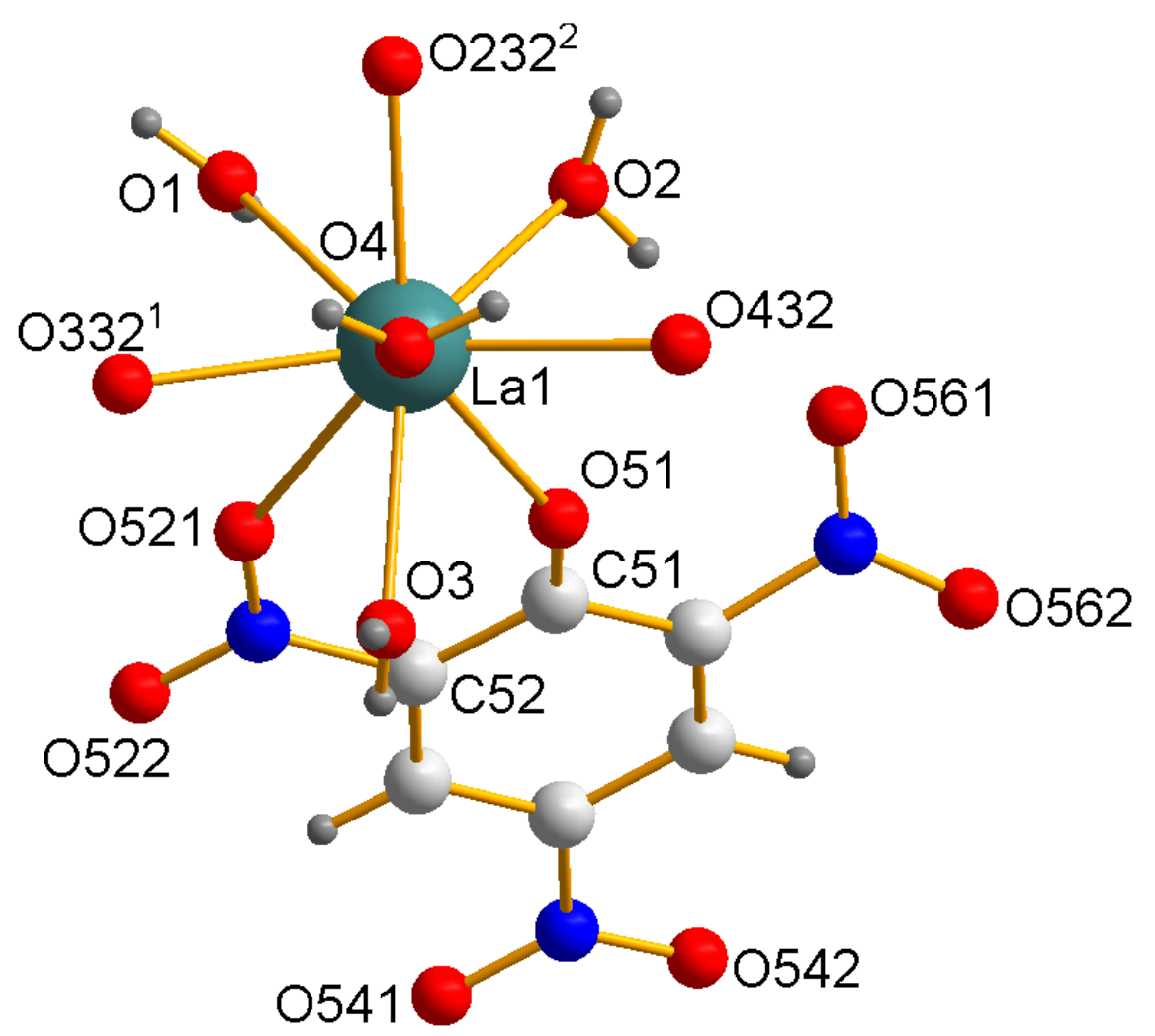

Figure 8 The 9-coordinate capped square antiprism coordination sphere of LaL projected approximately down the $\mathrm{O}(4)$ $\mathrm{La}(1)$ bond (the pseudo 4 axis). The superscripts refer to the atoms generated by the $2{ }_{1}$ screw $\left(^{1}\right.$ ) and the cell translation $\left({ }^{2}\right)$.

The angles between the pseudo 2-fold axis and the planes of each of the $\mathrm{Ph}$ rings are 91.08(8), $89.13(8)^{\circ}\left(1 \mathrm{n}\right.$ and $3 \mathrm{n}$ ) and $17.73(8), 12.47(8)^{\circ}(2 \mathrm{n}$ and $4 \mathrm{n})$. The angle between opposite 'vertical' pairs is $2.1(1)(1 \mathrm{n}$ and $3 n)$ and $30.1(1)^{\circ}(2 n$ and $4 n)$ between the 'horizontal' pairs. 
As observed in the $\mathrm{CaL}$ complex, there appears to be some interactions between the $\mathrm{Ph}$ ring (1n) and the coordinated picrate anions $(5 \mathrm{n})$. The angle between the two rings is $3.6(1)^{\circ}$ with the closest intra-molecular distances being $\mathrm{C}(13) \ldots \mathrm{N}(54)$ 3.396(4), $\mathrm{C}(14) \ldots \mathrm{C}(54)$ 3.454(4), and $\mathrm{O}(13) \ldots \mathrm{O}(541) 3.380(3) \AA$. There also appears to be interactions between the coordinated and one uncoordinated picrate with the interplanar angle being $2.9(1)^{\circ}$. Closest approaches are $\mathrm{O}(522) \ldots \mathrm{N}(76) 3.132(4), \mathrm{C}(55) \ldots \mathrm{O}(722) 3.231(4), \mathrm{C}(56) \ldots \mathrm{O}(722) 3.209(4), \mathrm{N}(56) \ldots \mathrm{O}(722) 3.099(4)$ A.

Three of the four amide NH groups are involved in intra-molecular hydrogen bonds to the methoxy oxygen atoms on the neighbouring $\mathrm{Ph}$ rings. The $\mathrm{H}$... O distances lie in the range 2.17 2.19 with the $\mathrm{N}-\mathrm{H}$...O angles ranging from 143.9 to $150.4^{\circ}$. The alcohol groups form hydrogen bonds to picrate anions, water molecules or in the case of $\mathrm{H}(334)$ to the alcohol oxygen atom $\mathrm{O}(134)$ of the molecule generated by the crystallographic $n$ glide plane. The coordinated water molecule $\mathrm{O}(2)$ forms an intramolecular hydrogen bond to the coordinated picrate, $\mathrm{H}(2 \mathrm{AO})$... $\mathrm{O}(561)$ $2.197(19) \AA, \mathrm{O}(2)-\mathrm{H}(2 \mathrm{AO}) \ldots \mathrm{O}(561) 174(4)^{\circ}$. There are also hydrogen bonds between the coordinated water molecules and the uncoordinated picrate anions, the solvent water molecules and also between $\mathrm{O}(4)$ and the amide oxygen atom $\mathrm{O}(132)$ and also between $\mathrm{O}(1)$ and the alcohol oxygen atom $\mathrm{O}(334)$. Details are tabulated in the SI.

\section{PrL}

The results of the structure determination of the praseodymium complex were consistent with the formulation $\left\{\left[\mathrm{PrL}\left(\mathrm{OH}_{2}\right)(\mathrm{HOMe})(\text { pic })_{2}\right](\text { pic }) \cdot 0.25 \mathrm{H}_{2} \mathrm{O} \cdot 2.75 \mathrm{CH}_{3} \mathrm{OH}\right\}_{n}$. (Figure 9, Figure S4) The structure is similar to the previous two complexes in terms of metal- $\mathbf{L}$ interactions, in this case forming a one-dimensional polymer where two of the three picrate anions are coordinated to the $\mathrm{Pr}$ atom with the third picrate not coordinated. The coordination around the Pr consists of one water molecule, one methanol molecule, two picrates both bound through the phenolic oxygen atom and a nitro group, and three ligand carbonyl groups, one from the ligand of the asymmetric unit, one from a ligand generated by a crystallographic inversion centre creating a centrosymmetric dimer (see Figure 9) and the third carbonyl from a ligand translated by one cell dimension in the $b$ direction. The metal is thus nine coordinated, but with a much different ligand set compared to LaL. The geometry is best described as a capped square antiprism as shown in Figure 10 projected down the pseudo 4-axis. 


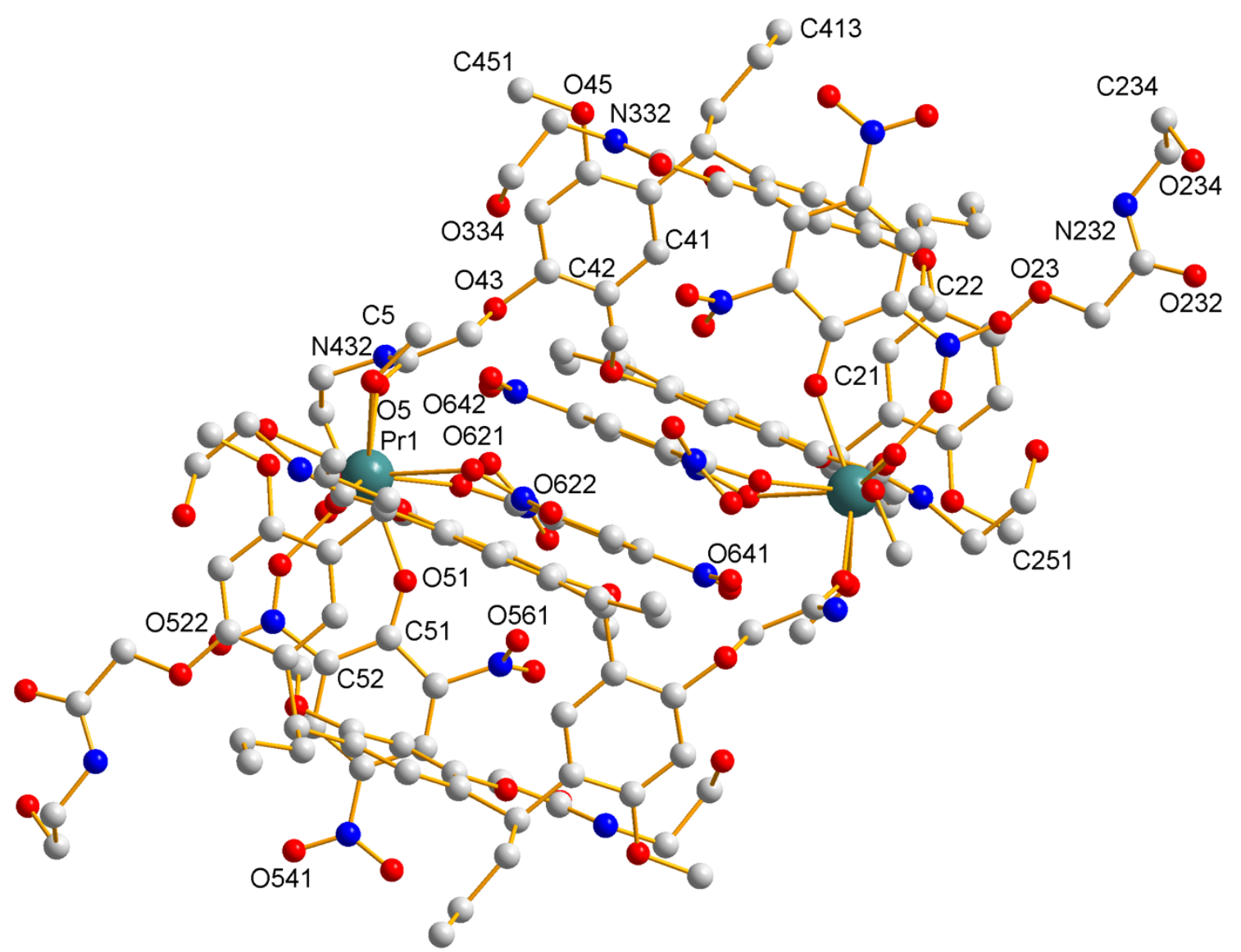

Figure 9 Molecular structure of PrL projected approximately onto the plane of the four $(\mathrm{CH})$ groups showing the dimeric component of the polymer. The minor components of the disordered atoms and hydrogen atoms have been omitted. 


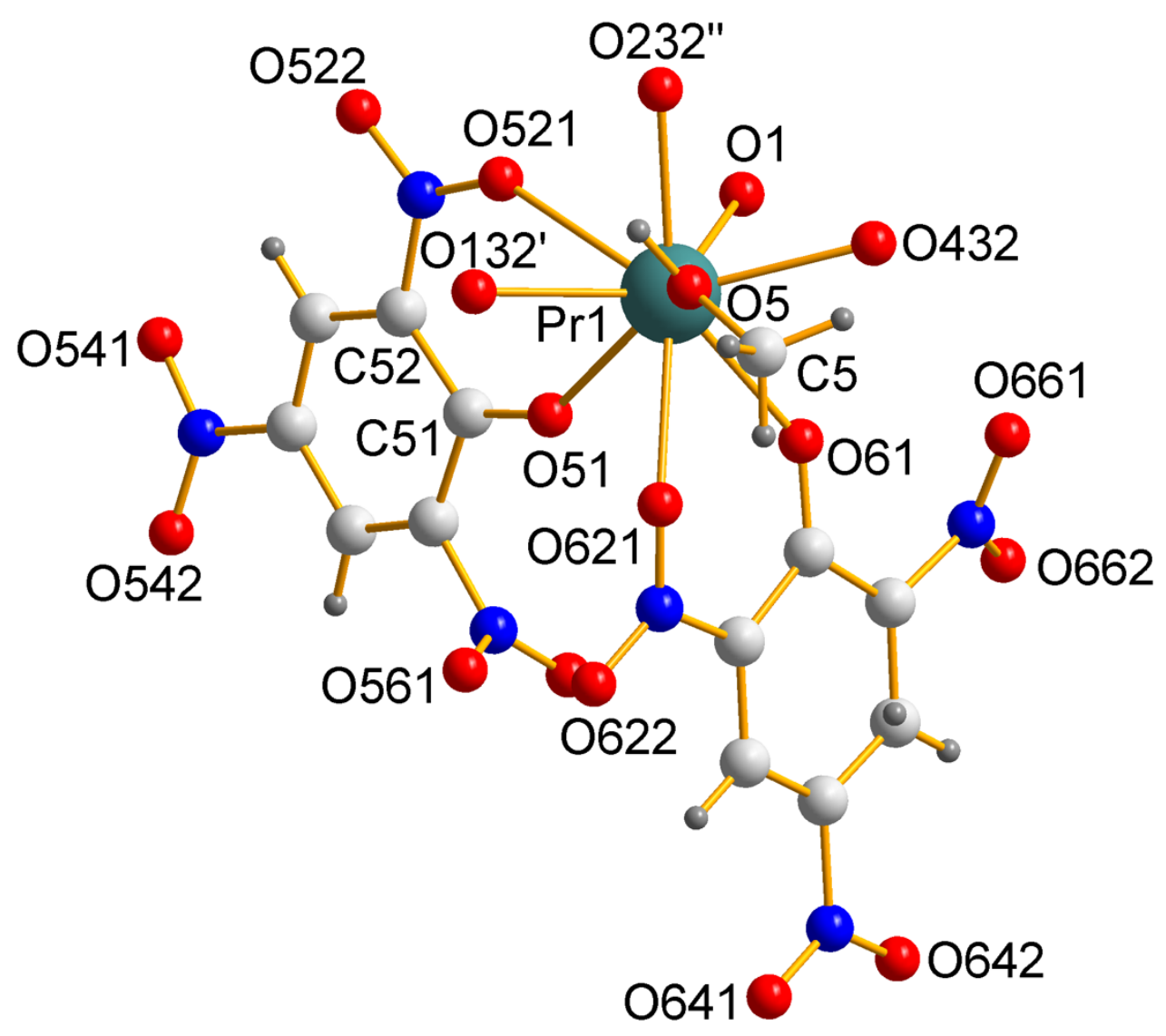

Figure 10 The 9-coordinate capped square antiprism coordination sphere of $\operatorname{Pr} \mathbf{L}$ projected approximately down the $\mathrm{O}(5)-\operatorname{Pr}(1)$ bond (the pseudo 4 axis). The " refers to the atom generated by 1-x,2-y,1-z with " referring to the atom generated by $1+\mathrm{x}, 1+\mathrm{y}, \mathrm{z}$.

The angles between the pseudo 2-fold axis and the planes of each of the $\mathrm{Ph}$ rings are $85.06(5), 87.35(5)^{\circ}(1 \mathrm{n}$ and $3 \mathrm{n})$ and $18.63(5), 15.91(5)^{\circ}(2 \mathrm{n}$ and $4 \mathrm{n})$. The angle between opposite 'vertical' pairs is 7.61(7) ( $1 \mathrm{n}$ and $3 \mathrm{n})$ and $34.37(7)^{\circ}(2 \mathrm{n}$ and $4 \mathrm{n})$ between the 'horizontal' pairs.

As was observed in the previous complexes, there appears to be some interactions between the $\mathrm{Ph}$ ring ( $1 \mathrm{n})$ and one of the coordinated picrate anions (6n). The angle between the two rings is $4.08(7)^{\circ}$ with the closest intra-molecular distances being $\mathrm{C}(13) \ldots \mathrm{N}(64)$ 3.354(3), $\mathrm{C}(14) \ldots \mathrm{C}(64)$ 3.383(3), and $\mathrm{O}(13) \ldots \mathrm{O}(641) 3.272(3) \AA$. The two coordinated picrate anions have a dihedral angle between the rings of $90.12(8)^{\circ}$.

Although hydrogen atoms were not located for the coordinated water molecule, some hydrogen interactions are observed. Two of the amide NH groups are involved in intra-molecular hydrogen bonds to methoxy oxygen atoms, the remaining two forming interactions to a solvent methanol molecule or the nitro group of the uncoordinated picrate group. As a result of the disorder, only two of the ligand hydroxyl hydrogen atoms were observed. One of these $\mathrm{H}(234)$ forms hydrogen bonds to carbonyl oxygen atom $\mathrm{O}(232)$ of the molecule related by an inversion centre with the hydrogen atom of the other hydroxyl $\mathrm{H}(334)$ forming hydrogen bonds to an oxygen atom 
of a nitro group of the uncoordinated picrate anion $(\mathrm{O}(741) / \mathrm{O}(871))$. Solvent methanol hydroxyl hydrogen atoms form hydrogen bonds to the coordinated hydroxyl group $(\mathrm{H}(5 \mathrm{O})$...O(234) $2.07 \AA)$, another methanol molecule $(\mathrm{H}(7) \ldots \mathrm{O}(8) 1.88 \AA$ ), and the uncoordinated picrate anion $(\mathrm{H}(6 \mathrm{O}) \ldots \mathrm{O}(8), \mathrm{H}(7) \ldots \mathrm{O}(842) \AA)$. Details are tabulated in the SI.

\section{$Y b L$}

The results of the structure determination of the ytterbium complex were consistent with the formulation $\left\{\left[\mathrm{YbL}\left(\mathrm{OH}_{2}\right)(\mathrm{pic})_{2}\right](\mathrm{pic}) \cdot \mathrm{H}_{2} \mathrm{O} \cdot 1.5 \mathrm{CH}_{3} \mathrm{OH}\right\}_{n}$. (Figure 11) The structure consisting of a one-dimensional polymer where two of the three picrate anions are coordinated to the $\mathrm{Yb}$ atom with the third picrate not coordinated. The coordination around the $\mathrm{Yb}$ therefore consists of one water molecule, two picrates both bound through the phenolic oxygen atom and a nitro group, and three ligand carbonyl groups, one from the ligand in the asymmetric unit, one from a ligand generated by a crystallographic inversion centre creating a centrosymmetric dimer (see Figure 12) and the third carbonyl from a ligand translated by one cell dimension in the $b$ direction. The metal is now eight coordinated, compared to nine coordinate for $\mathbf{L a} \mathbf{L}$ and $\operatorname{Pr} \mathbf{L}$, consistent with the smaller size of the $\mathrm{Yb}$ cation. The geometry is best described as a square antiprism as shown in Figure 13 projected down the pseudo 4-axis. The polymer is shown in Figure 14.

The angles between the pseudo 2-fold axis and the planes of each of the $\mathrm{Ph}$ rings are 83.1(2), 84.9(3) ${ }^{\circ}\left(1 \mathrm{n}\right.$ and $3 \mathrm{n}$ ) and $6.7(2), 8.5(2)^{\circ}(2 \mathrm{n}$ and $4 \mathrm{n})$. The angle between opposite 'vertical' pairs is $12.2(3)$ ( $1 \mathrm{n}$ and $3 \mathrm{n})$ and $15.2(3)^{\circ}(2 \mathrm{n}$ and $4 \mathrm{n})$ between the 'horizontal' pairs.

Again, a common feature is apparent interaction between the $\mathrm{Ph}$ ring (1n) and one of the coordinated picrate anions (6n). The angle between the two rings is $5.8(3)^{\circ}$ with the closest intramolecular distances being $\mathrm{C}(12) \ldots \mathrm{N}(64)$ 3.33(1), C(13)... (642) 3.36(1), C(14)..C(65) 3.25(1), and $\mathrm{O}(15) \ldots \mathrm{C}(66) 3.240(9) \AA$. The dihedral angle between the two coordinated picrate rings is much less than that observed in $\operatorname{Pr} \mathbf{L}$ at $31.5(5)^{\circ}$. 


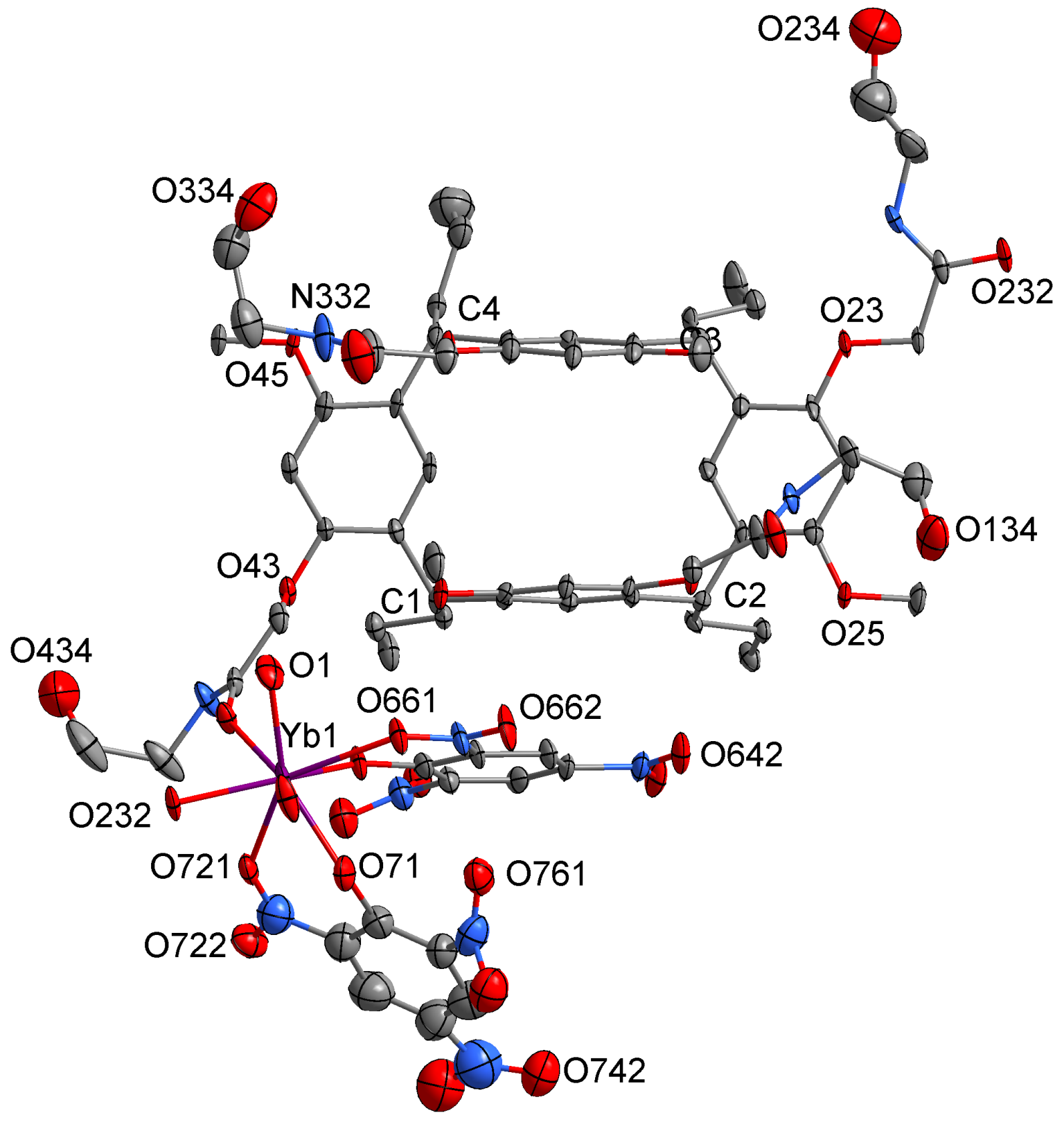

Figure 11 Molecular structure of $\mathrm{YbL}$. Hydrogen atoms and the minor components of the disordered atoms have been omitted. Ellipsoids have been drawn at the $30 \%$ probability level. 


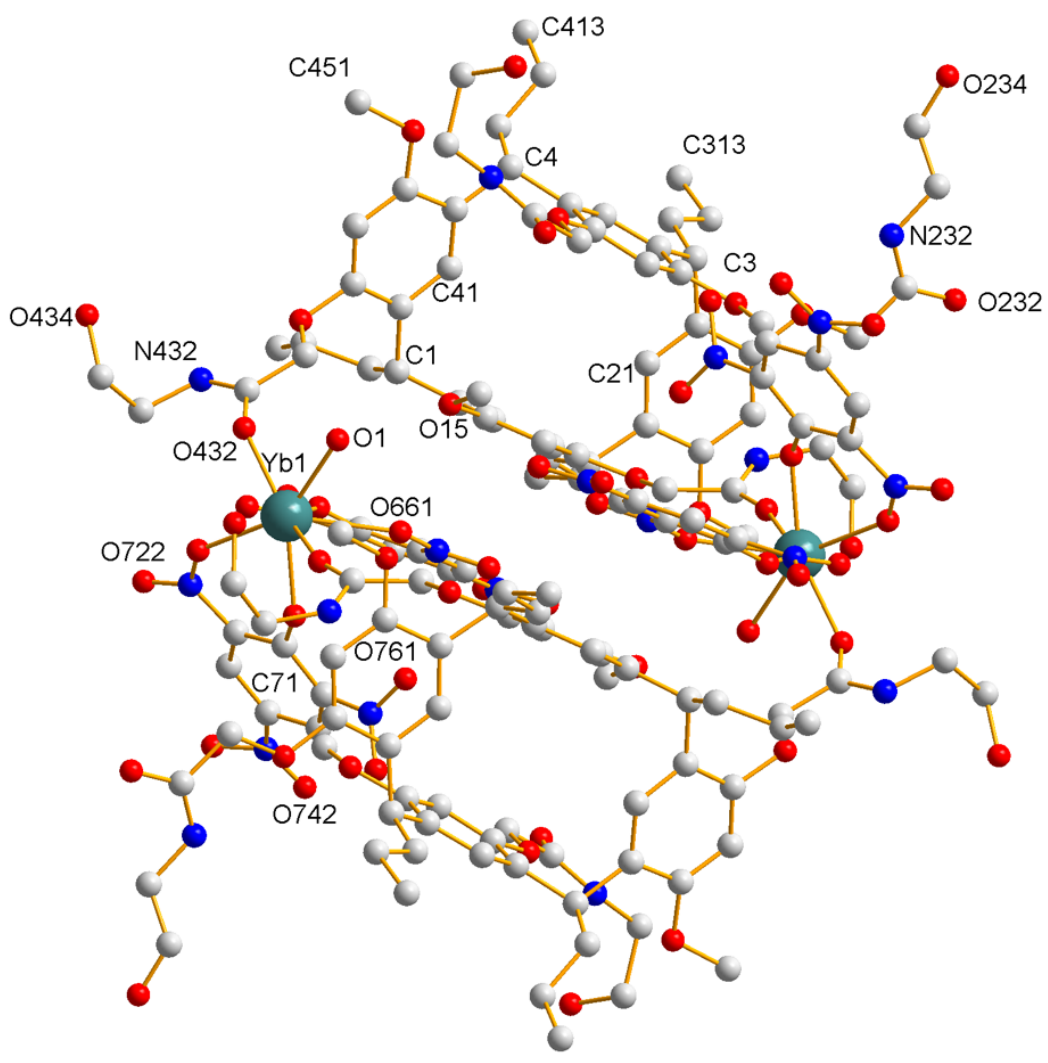

Figure 12 Molecular structure of YbL projected approximately onto the plane of the four $(\mathrm{CH})$ groups showing the dimeric component of the polymer. The minor components of the disordered atoms and hydrogen atoms have been omitted.

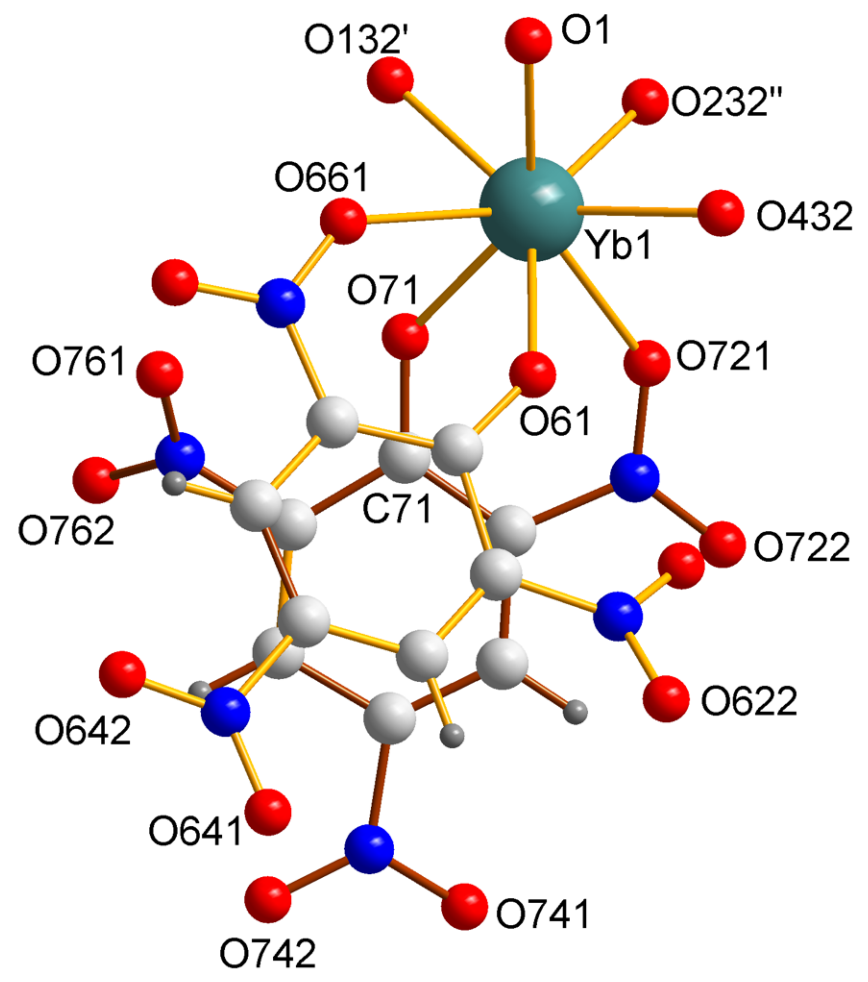

Figure 13 The 8-coordinate square antiprism coordination sphere of YbL projected approximately down the pseudo 4 axis. The " refers to the atom generated by $1-x, 1-y, 1-z$ with " referring to the atom generated by $\mathrm{x}, \mathrm{y}-1, \mathrm{z}$. 


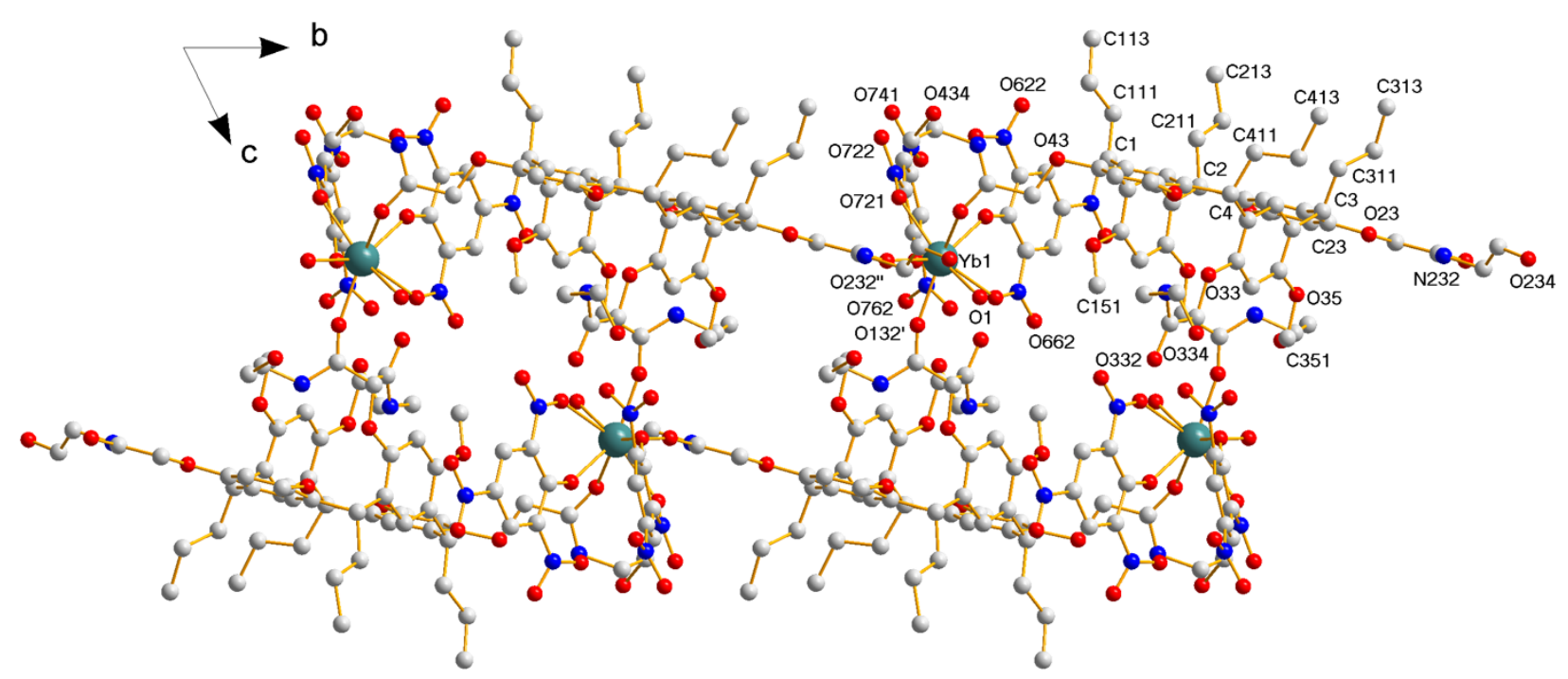

Figure 14 The one-dimension polymer of YbL projected down the $a$ axis.

\section{Structural Comparisons}

A remarkable aspect of these structure determinations is the consistent nature of the interactions between $\mathbf{L}$ and the various metal cations. In each case, the metal is bound to three amide $\mathrm{O}$ atoms, all from different $\mathbf{L}$ molecules, resulting in the formation of coordination polymers. The fourth amide $\mathrm{O}$ atom is left uncoordinated in each of the structures. That calcium should form a similar complex to lanthanoid complexes is consistent with the use of lanthanoids as calcium substitutes in biological systems. ${ }^{18}$ Structural similarities have previously been observed in the 1:1 calcium and europium complexes of p-t-butylcalix[8]arene. ${ }^{19}$ Simplified views of the macrocycle conformation and disposition of the three bound metal cations are shown for each of the complexes in Figure 15. $\mathrm{Ca} \mathbf{L}, \operatorname{Pr} \mathbf{L}$, and $\mathrm{YbL}$ are all very similar, consistent with their formation of one-dimensional coordination polymers. LaL differs somewhat in the disposition of the metal cations, and forms a two-dimensional polymer. It is possible that the consistent nature of these structures is also significantly impacted by the use of the picrate anion, with interactions between aromatic rings of the calixarene and picrate anions being observed in each case. Further work using different precursor metal salts will be required to further investigate this behavior. 
(a)

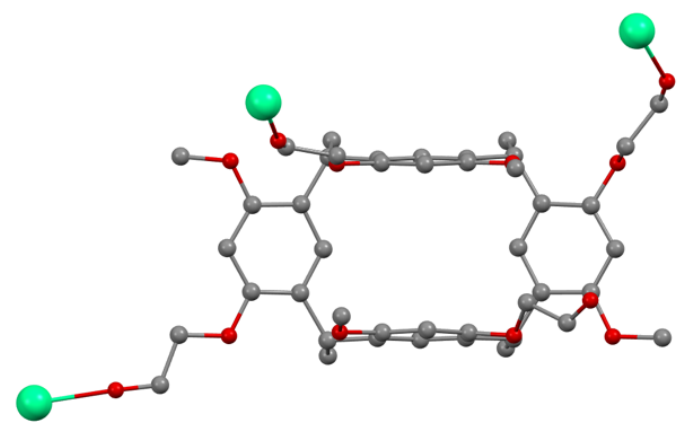

(c)

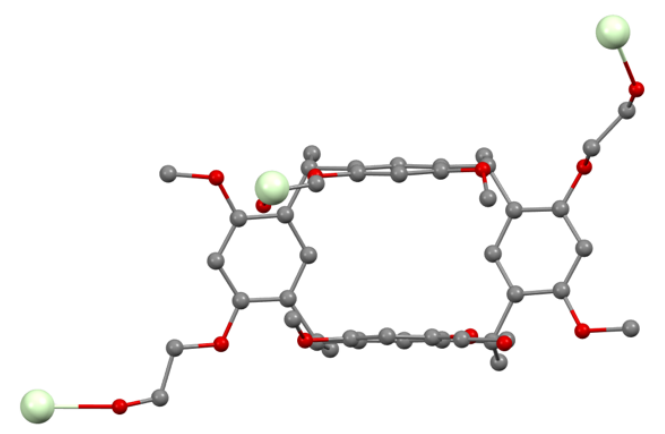

(b)

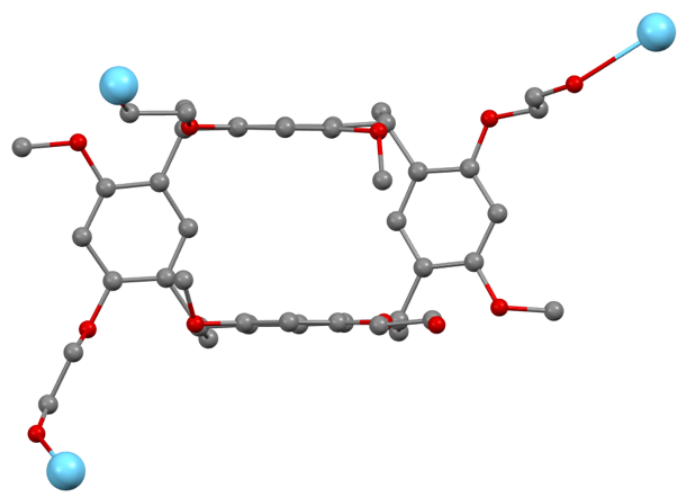

(d)

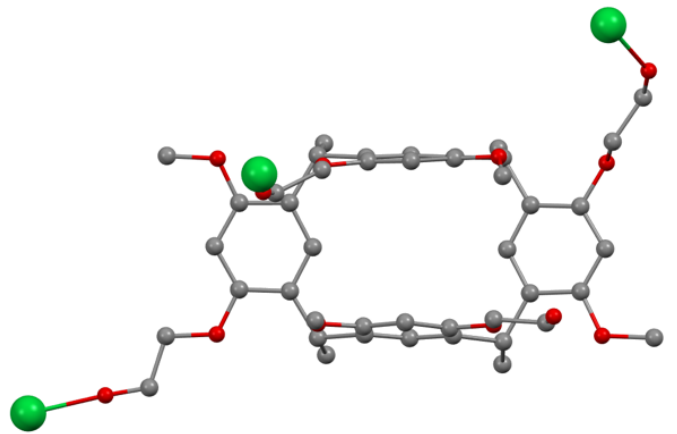

Figure 15 Simplified views emphasising the macrocycle conformation and metal-O(amide) interactions for (a) CaL, (b) LaL, (c) PrL, and (d) YbL.

\section{References}

1. McIldowie, M. J.; Mocerino, M.; Ogden, M. I., A brief review of C-n-symmetric calixarenes and resorcinarenes. Supramol Chem 2010, 22 (1), 13-39.

2. McIldowie, M. J.; Mocerino, M.; Ogden, M. I.; Skelton, B. W., Pyridine-functionalised C-4 symmetric resorcinarenes. Tetrahedron 2007, 63 (44), 10817-10825.

3. McIldowie, M. J.; Mocerino, M.; Ogden, M. I.; Skelton, B. W.; White, A. H., C-4

Dissymmetric resorcinarene derivatives: synthesis, crystal structure and micelle formation. $J$ Incl Phenom Macro 2015, 82 (1-2), 47-51.

4. McIldowie, M. J.; Mocerino, M.; Skelton, B. W.; White, A. H., Facile Lewis acid catalyzed synthesis of C-4 symmetric resorcinarenes. Org Lett 2000, 2 (24), 3869-3871.

5. Buckley, B. R.; Boxhall, J. Y.; Page, P. C. B.; Chan, Y.; Elsegood, M. R. J.; Heaney, H.; Holmes, K. E.; McIldowie, M. J.; Mckee, V.; McGrath, M. J.; Mocerino, M.; Poulton, A. M.; Sampler, E. P.; Skelton, B. W.; White, A. H., Mannich and O-alkylation reactions of tetraalkoxyresorcin[4]arenes - The use of some products in ligand-assisted reactions (pg 5117, 2006). Eur J Org Chem 2007, (7), 1203-1203.

6. Buckley, B. R.; Boxhall, J. Y.; Page, P. C. B.; Chan, Y. H.; Elsegood, M. R. J.; Heaney, H.; Holmes, K. E.; McIldowie, M. J.; McKee, V.; McGrath, M. J.; Mocerino, M.; Poulton, A. M.; Sampler, E. P.; Skelton, B. W.; White, A. H., Mannich and O-alkylation reactions of tetraalkoxyresorcin[4]arenes - The use of some products in ligand-assisted reactions. Eur J Org Chem 2006, (22), 5117-5134.

7. Buckley, B. R.; Page, P. C. B.; Chan, Y.; Heaney, H.; Klaes, M.; Mclldowie, M. J.; McKee, V.; Mattay, J.; Mocerino, M.; Moreno, E.; Skelton, B. W.; White, A. H., The preparation and absolute configurations of enantiomerically pure C-4-symmetric tetraalkoxyresorcin[4]arenes obtained from camphorsulfonate derivatives. Eur J Org Chem 2006, (22), 5135-5151.

8. Salorinne, K.; Nissinen, M., Novel tetramethoxy resorcinarene bis-crown ethers. Org Lett 2006, $8(24), 5473-5476$. 
9. Tero, T. R.; Suhonen, A.; Salorinne, K.; Campos-Barbosa, H.; Nissinen, M., The Missing Member of the Partially O-Alkylated Resorcinarene Family: Synthesis and Conformation of Methyl Tetramethoxy Resorcinarene. Org Lett 2013, 15 (5), 1096-1099.

10. Tan, Y. J.; Mocerino, M.; Paterson, T., Organic molecules showing the characteristics of localised corrosion aggravation and inhibition. Corros Sci 2011, 53 (5), 2041-2045.

11. Diakiw, V.; Hambley, T. W.; Kepert, D. L.; Raston, C. L.; White, A. H., Crystal-Structure of Calcium Picrate Pentahydrate - New 8-Coordinate Stereochemistry for [M(Bidentate) $)_{2}$ (Unidentate) $\left.)_{4}\right]$. Aust J Chem 1979, 32 (2), 301-309.

12. Harrowfield, J. M.; Lu, W. M.; Skelton, B. W.; White, A. H., Structural Systematics of RareEarth Complexes .1. Structural Characterization of Lanthanoid(III) Picrate Hydrates Monoclinic $\left(P 2_{1} / c\right)$ (Quasi-)Dodecahydrates of the Related La -] Pr and Nd -] Tb Families. Aust J Chem 1994, 47 (2), 321-337.

13. Harrowfield, J. M.; Lu, W. M.; Skelton, B. W.; White, A. H., Structural Systematics of RareEarth Complexes .2. Structural Characterization of Lanthanoid(III) Picrate Hydrates - the Triclinic $P \overline{1}, 11.5$ Hydrates of the Later Rare-Earths and Yttrium. Aust J Chem 1994, 47 (2), 339-348.

14. Sheldrick, G. M., Crystal structure refinement with SHELXL. Acta Crystallogr C 2015, 71, 38 .

15. Sun, J.; Zhang, L. L.; Yao, Y.; Yan, C. G., Synthesis, crystal structures and complexing properties of tetramethoxyresorcinarene functionalized tetraacylhydrazones. J Incl Phenom Macro 2014, 79 (3-4), 485-494.

16. Li, L.; Sun, J.; Zhang, L. L.; Yao, R.; Yan, C. G., Crystal structure and fluorescence sensing properties of tetramethoxyresorcinarene functionalized Schiff bases. J Mol Struct 2015, 1081, 355-361.

17. Puttreddy, R.; Beyeh, N. K.; Rissanen, K., Conformational changes in C-methyl-resorcinarene pyridine N-oxide inclusion complexes in the solid state. Crystengcomm 2016, 18 (26), 4971 4976.

18. Hewitt, S. H.; Butler, S. J., Application of lanthanide luminescence in probing enzyme activity. Chem Commun 2018, 54 (50), 6635-6647.

19. Harrowfield, J. M.; Ogden, M. I.; Richmond, W. R.; White, A. H., Lanthanide Ions as Calcium Substitutes - a Structural Comparison of Europium and Calcium Complexes of Ditopic Calixarene. J Chem Soc Dalton 1991, (8), 2153-2160. 
Metal coordination with an amide-functionalized axially chiral resorcinarene

Jamila Vaughan, Munna Ali Mohamed Bertata, Brian W. Skelton, Mark I. Ogden, and Mauro Mocerino*

Supplementary Information

Crystal Structure of $1^{4}, 3^{6}, 5^{6}, 7^{6}$-tetraethoxycarbonylmethyleneoxy $-1^{6}, 3^{4}, 5^{4}, 7^{4}$ tetramethoxy-2,4,6,8- tetrapropylresorcin[4]arene, 2

Crystal structure of $1^{4}, 3^{6}, 5^{6}, 7^{6}$-tetra-2-oxo-2-(2-hydroxyethylamino)ethoxy-1 $1^{6}, 3^{4}, 5^{4}, 7^{4}$ -

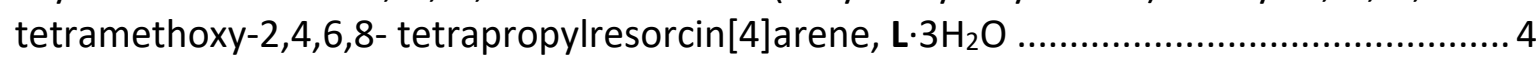

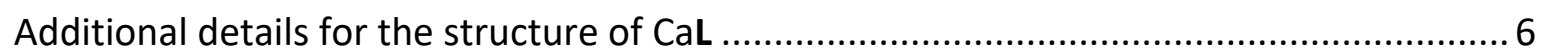

Additional details for the structure of LaL................................................................... 8

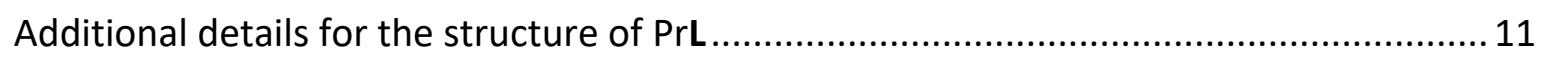

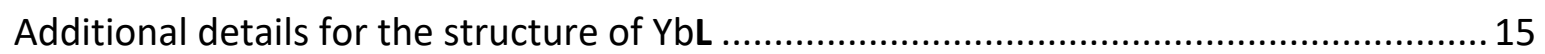


Crystal Structure of $1^{4}, 3^{6}, 5^{6}, 7^{6}$-tetraethoxycarbonylmethyleneoxy $-1^{6}, 3^{4}, 5^{4}, 7^{4}$ tetramethoxy-2,4,6,8- tetrapropy|resorcin[4]arene, 2

A crystal of 2 was grown by slow evaporation of an ethanol solution, and was characterised by single crystal X-ray crystallography. The crystal data for $\mathbf{2}$ are summarized in Table S1 with the structure depicted in Figs. S1 and S2 where ellipsoids have been drawn at the 50\% probability level. Crystallographic data for the structures were collected at 100(2) K on an Oxford Diffraction Gemini diffractometer using Mo Ka radiation. Following multi-scan absorption corrections, the structure was refined against $F^{2}$ with full-matrix least-squares using the program SHELXL-2017. ${ }^{1}$ One ethoxycarbonylmethoxy group was modelled as being disordered over two sets of sites with sites occupancies refined to 0.835(4) and its complement. The methyl group of the methoxy group on the opposite $\mathrm{Ph}$ ring was also modelled as being disordered over two sets of sites, with occupancies refined to 0.744(7) and its complement. All $\mathrm{H}$-atoms were added at calculated positions and refined by use of a riding model with isotropic displacement parameters based on those of the parent atom. Anisotropic displacement parameters were employed for all the non-hydrogen atoms. Full details of the structure determinations for $\mathbf{2}$ have been deposited with the Cambridge Crystallographic Data Centre as CCDC 1842968.

Table S1. Crystal data and structure refinement for 2.

Empirical formula

Formula weight

Temperature

Wavelength

Crystal system

Space group

Unit cell dimensions

Volume

$Z$

Density (calculated)

$\mu$

$\mathrm{F}(000)$

Crystal size

$\theta$ range for data collection

Index ranges

Reflections collected

Independent reflections

Completeness to $\theta=25.242^{\circ}$

Absorption correction

Max./min. transmission

Refinement method

Data / restraints / parameters

Goodness-of-fit on $F^{2}$

Final $R$ indices $[I>2 \sigma(I)]$

$R$ indices (all data)

Largest diff. peak and hole

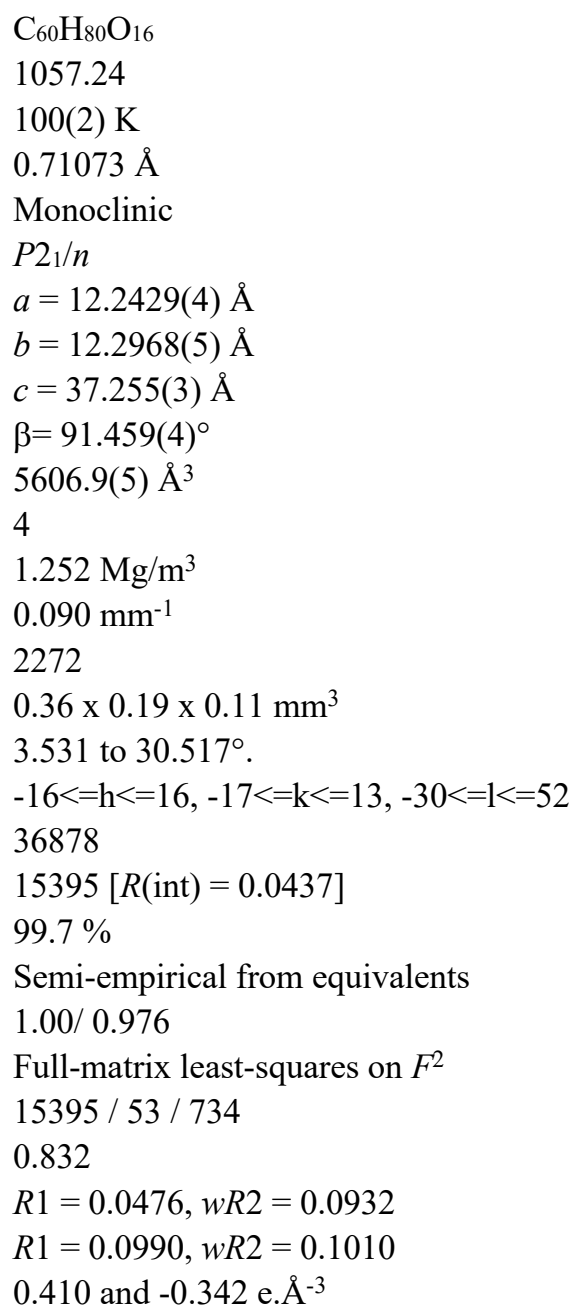




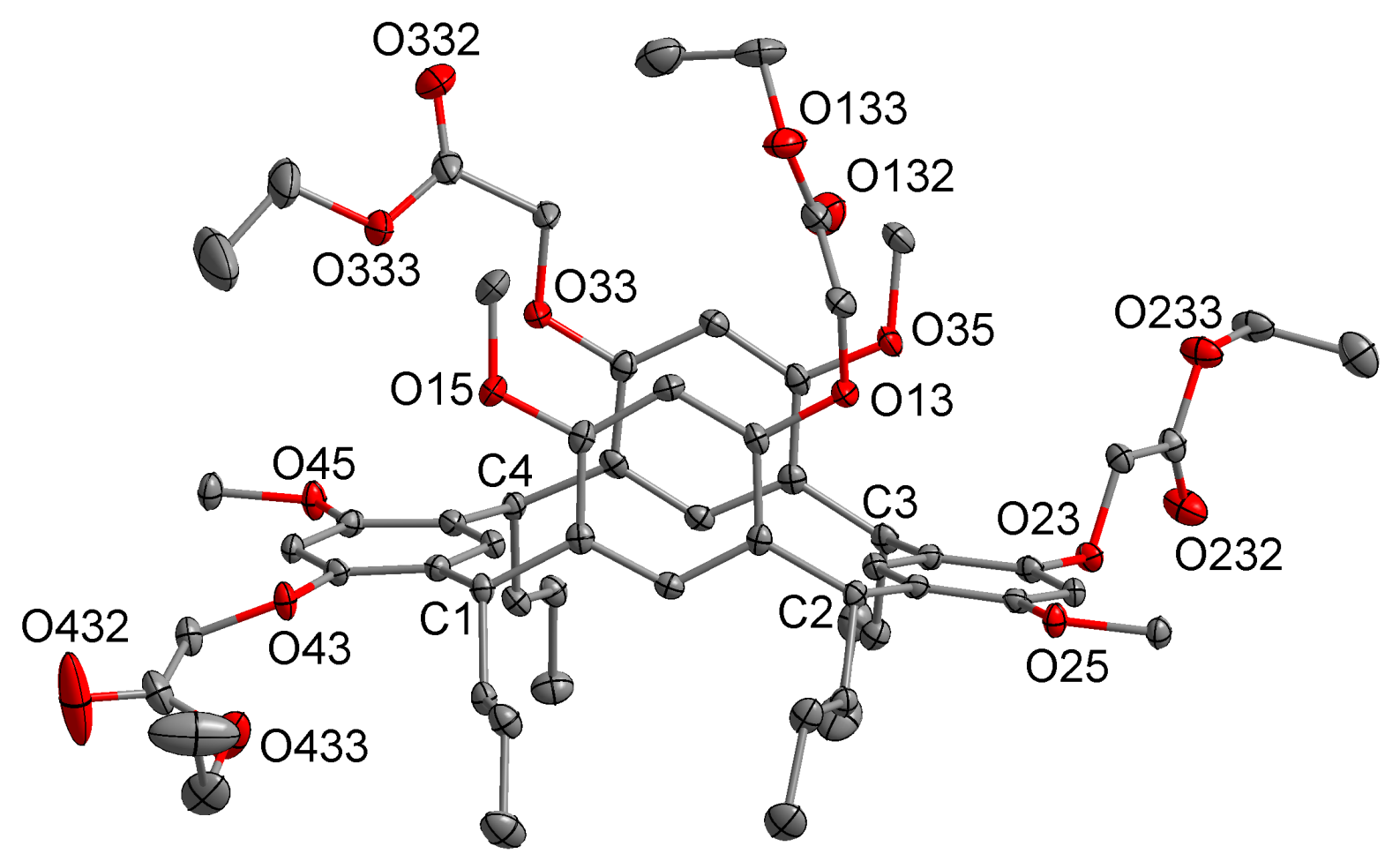

Fig. S1 Molecular structure of 2 . Only one set of disordered atoms is shown. Hydrogen atoms have been omitted.

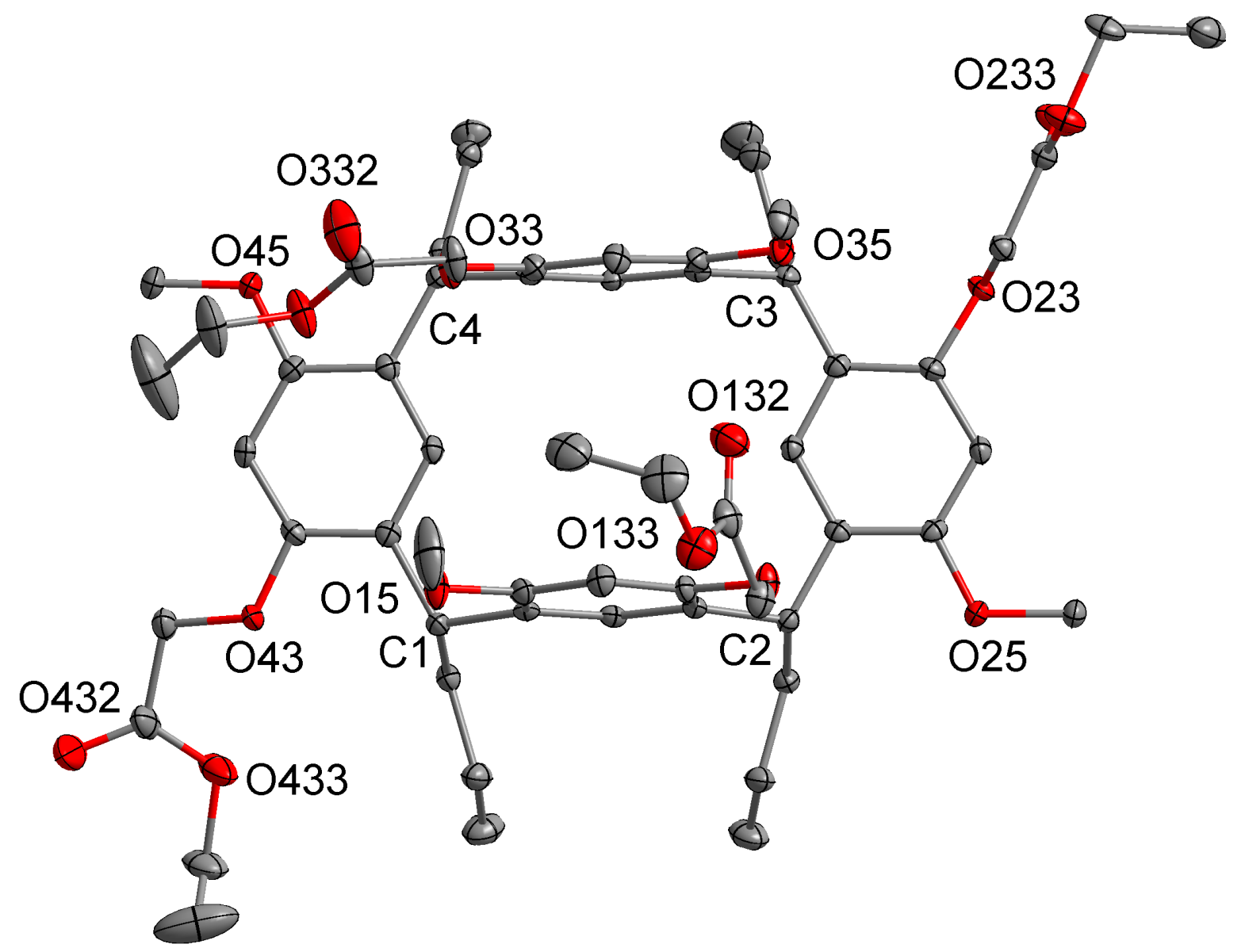

Fig. S2 Molecular structure of 2 projected approximately onto the plane of the four $(\mathrm{CH})$ groups. Only one set of disordered atoms is shown. Hydrogen atoms have been omitted. 
The crystal data for $\mathbf{L} \cdot 3 \mathrm{H}_{2} \mathrm{O}$ are summarized in Table $\mathrm{S} 2$ with the structure depicted in Fig. S3 where ellipsoids have been drawn at the $30 \%$ probability level. Crystallographic data for the structures were collected at 100(2) K on an Oxford Diffraction Gemini diffractometer using $\mathrm{Cu} \mathrm{K} \alpha$ radiation. Following solution by direct methods and multi-scan absorption corrections, the structure was refined against $F^{2}$ with full-matrix least-squares using the program SHELXL$2017 .{ }^{1}$ The terminal oxygen atoms of three of the four hydroxylethanolamide chains were each modelled as being disordered over two sets of sites with occupancies set at 0.5 after trial refinement. The terminal two atoms on the $\mathrm{nPr}$ chain, $\mathrm{C}(31 \mathrm{n})$, were also modelled as disordered with occupancies set at 0.5 . The occupancies of the water molecules O1-O5 were constrained to 1.0 or 0.5 from trial refinement. Hydrogen atoms on the disordered hydroxylethanolamide chains and disordered solvent water molecules were not located nor could their positions be readily determined from possible hydrogen bonding interactions. Hydrogen atoms for water molecule $\mathrm{O} 1$ and for $\mathrm{O} 234$ were included at positions suitable for hydrogen bonding and refined with geometrical restraints.

Geometries involving the disordered atoms were restrained to ideal values. Anisotropic displacement parameters were employed for all non-hydrogen atoms. All remaining H-atoms were added at calculated positions and refined by use of a riding model with isotropic displacement parameters based on those of the parent atom. Table S3 lists the hydrogen bonding for those hydrogen atoms which could be located. Full details of the structure determinations for $\mathbf{L} \cdot 3 \mathrm{H}_{2} \mathrm{O}$ have been deposited with the Cambridge Crystallographic Data Centre as CCDC 1896386.

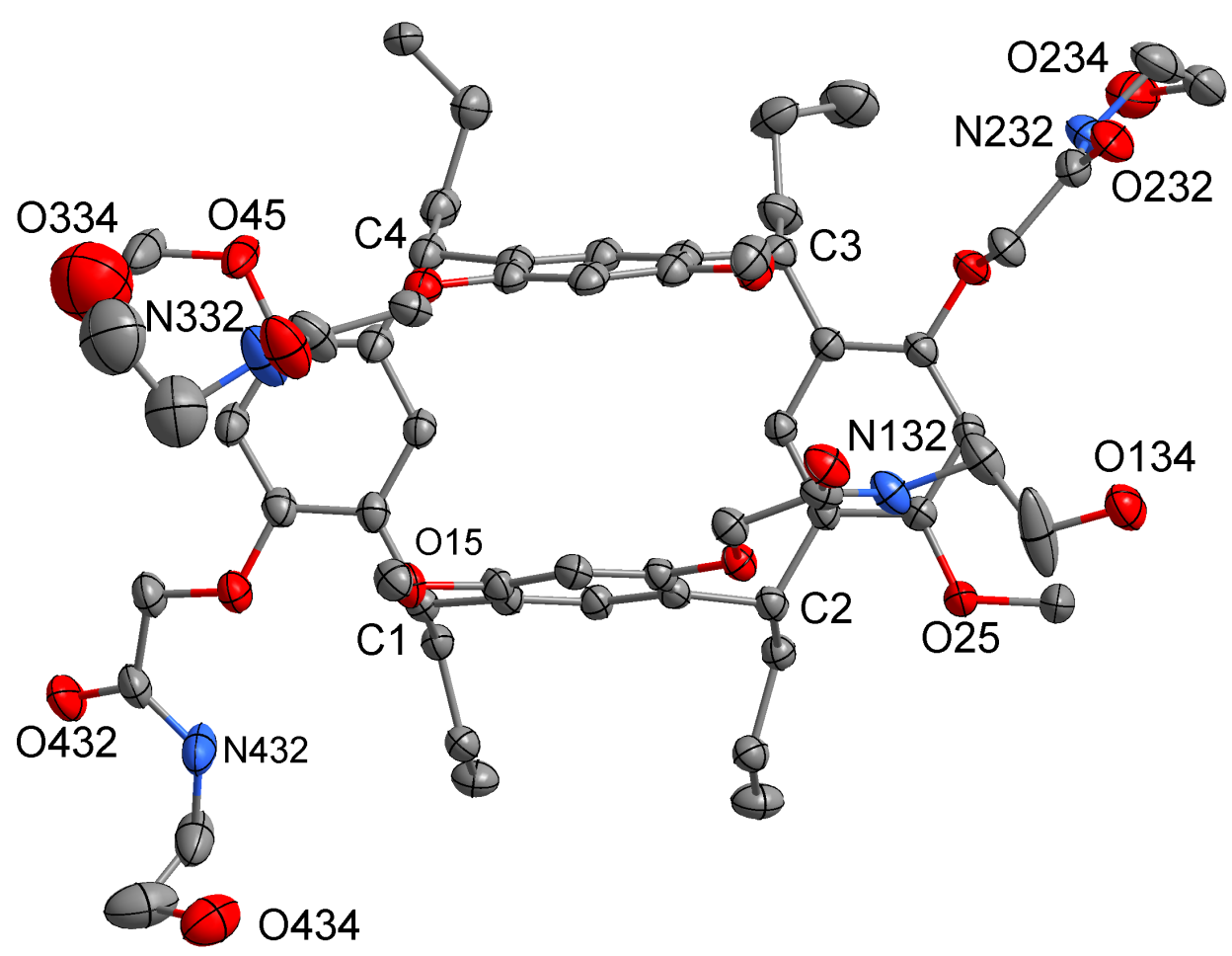

Fig. S3 Molecular structure of $\mathbf{L} \cdot 3 \mathrm{H}_{2} \mathrm{O}$ projected approximately onto the plane of the four $\mathrm{CH}$ groups. Only the atoms of one, or major, component of the disorder are shown. 
Table S2. Crystal data and structure refinement for $\mathbf{L} \cdot 3 \mathrm{H}_{2} \mathrm{O}$.

Empirical formula

Formula weight

Temperature

Wavelength

Crystal system

Space group

Unit cell dimensions

Volume

Z

Density (calculated)

$\mu$

$\mathrm{F}(000)$

Crystal size

$\theta$ range for data collection

Index ranges

Reflections collected

Independent reflections

Completeness to $\theta=67.315^{\circ}$

Absorption correction

Max./min. transmission

Refinement method

Data / restraints / parameters

Goodness-of-fit on $F^{2}$

Final R indices $[I>2 \sigma(I)]$

$R$ indices (all data)

Largest diff. peak and hole
$\mathrm{C}_{60} \mathrm{H}_{9} \mathrm{~N}_{4} \mathrm{O}_{19}$

1171.35

100(2) K

$1.54184 \AA$

Triclinic

$P \overline{1}$

$a=13.8753(9) \AA$

$b=15.3332(10) \AA$

$c=16.1724(11) \AA$

$\alpha=83.896(5)^{\circ}$

$\beta=69.456(6)^{\circ}$

$\gamma=74.517(6)^{\circ}$

3104.7(4) $\AA^{3}$

2

$1.253 \mathrm{Mg} / \mathrm{m}^{3}$

$0.768 \mathrm{~mm}^{-1}$

1260

$0.43 \times 0.24 \times 0.04 \mathrm{~mm}^{3}$

2.918 to $67.315^{\circ}$.

$-16<=\mathrm{h}<=8,-18<=\mathrm{k}<=18,-19<=\mathrm{l}<=19$

26248

$10964[R($ int $)=0.0689]$

$98.3 \%$

Semi-empirical from equivalents

$1.00 / 0.553$

Full-matrix least-squares on $\mathrm{F}^{2}$

10964 / 42 / 818

0.957

$R 1=0.0990, w R 2=0.2630$

$R 1=0.1573, w R 2=0.3075$

0.718 and -0.633 e. $\AA^{-3}$

Table S3. Hydrogen bonds for $\mathbf{L} \cdot 3 \mathrm{H}_{2} \mathrm{O}\left[\AA\right.$ and ${ }^{\circ}$ ].

\begin{tabular}{lcccc}
\hline D-H...A & d(D-H) & d(H...A & $d($ D...A $)$ & $<($ DHA $)$ \\
\hline $\mathrm{N}(232)-\mathrm{H}(232) \ldots \mathrm{O}(23)$ & 0.88 & 2.12 & $2.571(5)$ & 110.7 \\
$\mathrm{O}(234)-\mathrm{H}(234) \ldots \mathrm{O}(332)^{1}$ & 0.84 & 2.22 & $2.600(7)$ & 107.5 \\
$\mathrm{~N}(432)-\mathrm{H}(432) \ldots \mathrm{O}(135)^{2}$ & 0.88 & 2.65 & $3.315(15)$ & 132.9 \\
$\mathrm{O}(1)-\mathrm{H}(1 \mathrm{~B}) \ldots \mathrm{O}(232)$ & 0.84 & 2.12 & $2.689(10)$ & 124.3 \\
$\mathrm{O}(1)-\mathrm{H}(1 \mathrm{~A}) \ldots \mathrm{O}(3)^{3}$ & 0.84 & 1.82 & $2.595(16)$ & 153.4
\end{tabular}

Symmetry transformations used to generate equivalent atoms:

${ }^{1} \mathrm{x}, \mathrm{y}, \mathrm{z}+1 ; \quad{ }^{2} 1-\mathrm{x}, 1-\mathrm{y},-\mathrm{z} ;{ }^{3}-\mathrm{x}, 1-\mathrm{y}, 1-\mathrm{z}$ 
Additional details for the structure of CaL

Table S4. Selected bond lengths [A] and angles $\left[{ }^{\circ}\right]$ for CaL.

\begin{tabular}{lr}
\hline $\mathrm{Ca}(1)-\mathrm{O}(132)^{1}$ & $2.270(3)$ \\
$\mathrm{Ca}(1)-\mathrm{O}(51)$ & $2.274(3)$ \\
$\mathrm{Ca}(1)-\mathrm{O}(432)$ & $2.298(3)$ \\
$\mathrm{Ca}(1)-\mathrm{O}(1)$ & $2.332(4)$ \\
$\mathrm{Ca}(1)-\mathrm{O}(232)^{2}$ & $2.332(3)$ \\
$\mathrm{Ca}(1)-\mathrm{O}(5)$ & $2.366(3)$ \\
& \\
$\mathrm{O}(132)^{1}-\mathrm{Ca}(1)-\mathrm{O}(51)$ & $107.32(11)$ \\
$\mathrm{O}(132)^{1}-\mathrm{Ca}(1)-\mathrm{O}(432)$ & $163.60(12)$ \\
$\mathrm{O}(51)-\mathrm{Ca}(1)-\mathrm{O}(432)$ & $86.60(10)$ \\
$\mathrm{O}(132)^{1}-\mathrm{Ca}(1)-\mathrm{O}(1)$ & $91.41(17)$ \\
$\mathrm{O}(51)-\mathrm{Ca}(1)-\mathrm{O}(1)$ & $85.58(14)$ \\
$\mathrm{O}(432)-\mathrm{Ca}(1)-\mathrm{O}(1)$ & $98.44(16)$ \\
$\mathrm{O}(132)^{1}-\mathrm{Ca}(1)-\mathrm{O}(232)^{2}$ & $86.30(10)$ \\
$\mathrm{O}(51)-\mathrm{Ca}(1)-\mathrm{O}(232)^{2}$ & $159.01(12)$ \\
$\mathrm{O}(432)-\mathrm{Ca}(1)-\mathrm{O}(232)^{2}$ & $82.99(9)$ \\
$\mathrm{O}(1)-\mathrm{Ca}(1)-\mathrm{O}(232)^{2}$ & $78.02(14)$ \\
$\mathrm{O}(132)^{1}-\mathrm{Ca}(1)-\mathrm{O}(5)$ & $88.25(13)$ \\
$\mathrm{O}(51)-\mathrm{Ca}(1)-\mathrm{O}(5)$ & $104.33(12)$ \\
$\mathrm{O}(432)-\mathrm{Ca}(1)-\mathrm{O}(5)$ & \\
$\mathrm{O}(1)-\mathrm{Ca}(1)-\mathrm{O}(5)$ & \\
$\mathrm{O}(232)^{2}-\mathrm{Ca}(1)-\mathrm{O}(5)$ & \\
& \\
& \\
& \\
& \\
&
\end{tabular}

Symmetry transformations used to generate equivalent atoms:

$1-\mathrm{x}, 1-\mathrm{y}, 1-\mathrm{z} ;{ }^{2} \mathrm{x}-1, \mathrm{y}-1, \mathrm{z}$ 
Table S5. Hydrogen bonds for $\mathrm{CaL}\left[\AA \stackrel{\text { and }}{ }{ }^{\circ}\right]$.

\begin{tabular}{lcccc}
\hline D-H...A & $\mathrm{d}(\mathrm{D}-\mathrm{H})$ & $\mathrm{d}(\mathrm{H} \ldots \mathrm{A})$ & $\mathrm{d}(\mathrm{D} \ldots \mathrm{A})$ & $<(\mathrm{DHA})$ \\
\hline $\mathrm{N}(132)-\mathrm{H}(132) \ldots \mathrm{O}(25)$ & 0.88 & 2.31 & $3.066(14)$ & 143.5 \\
$\mathrm{~N}(135)-\mathrm{H}(135) \ldots \mathrm{O}(25)$ & 0.88 & 2.31 & $2.987(11)$ & 133.8 \\
$\mathrm{~N}(232)-\mathrm{H}(232) \ldots \mathrm{O}(641)^{2}$ & 0.88 & 2.30 & $3.009(4)$ & 138.0 \\
$\mathrm{~N}(332)-\mathrm{H}(332) \ldots \mathrm{O}(33)$ & 0.88 & 2.07 & $2.528(5)$ & 111.6 \\
$\mathrm{~N}(332)-\mathrm{H}(332) \ldots \mathrm{O}(61)^{2}$ & 0.88 & 2.29 & $3.106(6)$ & 154.8 \\
$\mathrm{O}(334)-\mathrm{H}(334) \ldots \mathrm{O}(1)^{2}$ & 0.84 & 2.17 & $2.764(7)$ & 128.1 \\
$\mathrm{O}(434)-\mathrm{H}(434) \ldots \mathrm{O}(621)^{3}$ & 0.84 & 2.34 & $3.124(4)$ & 155.1 \\
$\mathrm{O}(5)-\mathrm{H}(5) \ldots \mathrm{O}(3)^{1}$ & 0.95 & 1.89 & $2.811(6)$ & 162.2 \\
$\mathrm{O}(6)-\mathrm{H}(6) \ldots \mathrm{O}(61)$ & 0.84 & 1.92 & $2.658(4)$ & 146.5 \\
$\mathrm{O}(6)-\mathrm{H}(6) \ldots \mathrm{O}(621)$ & 0.84 & 2.38 & $3.019(4)$ & 133.9 \\
$\mathrm{O}(7)-\mathrm{H}(7) \ldots \mathrm{O}(434)$ & 0.84 & 2.00 & $2.817(4)$ & 165.7 \\
& & & & \\
\hline
\end{tabular}

Symmetry transformations used to generate equivalent atoms:

$1 \mathrm{x}-1, \mathrm{y}-1, \mathrm{z} ; \quad{ }^{2} \mathrm{x}+1, \mathrm{y}, \mathrm{z} ; \quad{ }^{3}-\mathrm{x}, 1-\mathrm{y}, 2-\mathrm{z}$ 
Additional details for the structure of LaL

Table S6. Selected bond lengths [A] and angles $\left[{ }^{\circ}\right]$ for LaL.

\begin{tabular}{|c|c|}
\hline $\mathrm{La}(1)-\mathrm{O}(432)$ & $2.465(3)$ \\
\hline $\mathrm{La}(1)-\mathrm{O}(332)^{1}$ & $2.465(3)$ \\
\hline $\mathrm{La}(1)-\mathrm{O}(51)$ & $2.479(3)$ \\
\hline $\mathrm{La}(1)-\mathrm{O}(232)^{2}$ & $2.488(3)$ \\
\hline $\mathrm{La}(1)-\mathrm{O}(1)$ & $2.537(3)$ \\
\hline $\mathrm{La}(1)-\mathrm{O}(3)$ & $2.567(3)$ \\
\hline $\mathrm{La}(1)-\mathrm{O}(4)$ & 2.574(3) \\
\hline $\mathrm{La}(1)-\mathrm{O}(2)$ & $2.607(3)$ \\
\hline $\mathrm{La}(1)-\mathrm{O}(521)$ & $2.710(3)$ \\
\hline $\mathrm{O}(432)-\mathrm{La}(1)-\mathrm{O}(332)^{1}$ & 143.99(9) \\
\hline $\mathrm{O}(432)-\mathrm{La}(1)-\mathrm{O}(51)$ & $73.66(8)$ \\
\hline $\mathrm{O}(332)^{1}-\mathrm{La}(1)-\mathrm{O}(51)$ & $126.18(9)$ \\
\hline $\mathrm{O}(432)-\mathrm{La}(1)-\mathrm{O}(232)^{2}$ & $85.40(9)$ \\
\hline $\mathrm{O}(332)^{1}-\mathrm{La}(1)-\mathrm{O}(232)^{2}$ & $89.87(9)$ \\
\hline $\mathrm{O}(51)-\mathrm{La}(1)-\mathrm{O}(232)^{2}$ & $140.86(9)$ \\
\hline $\mathrm{O}(432)-\mathrm{La}(1)-\mathrm{O}(1)$ & $138.57(11)$ \\
\hline $\mathrm{O}(332)^{1}-\mathrm{La}(1)-\mathrm{O}(1)$ & $71.17(11)$ \\
\hline $\mathrm{O}(51)-\mathrm{La}(1)-\mathrm{O}(1)$ & $104.25(10)$ \\
\hline $\mathrm{O}(232)^{2}-\mathrm{La}(1)-\mathrm{O}(1)$ & $70.54(11)$ \\
\hline $\mathrm{O}(432)-\mathrm{La}(1)-\mathrm{O}(3)$ & $86.09(10)$ \\
\hline $\mathrm{O}(332)^{1}-\mathrm{La}(1)-\mathrm{O}(3)$ & $74.03(10)$ \\
\hline $\mathrm{O}(51)-\mathrm{La}(1)-\mathrm{O}(3)$ & $73.82(10)$ \\
\hline $\mathrm{O}(232)^{2}-\mathrm{La}(1)-\mathrm{O}(3)$ & $138.32(10)$ \\
\hline $\mathrm{O}(1)-\mathrm{La}(1)-\mathrm{O}(3)$ & $134.07(11)$ \\
\hline $\mathrm{O}(432)-\mathrm{La}(1)-\mathrm{O}(4)$ & $70.12(9)$ \\
\hline $\mathrm{O}(332)^{1}-\mathrm{La}(1)-\mathrm{O}(4)$ & $74.59(9)$ \\
\hline $\mathrm{O}(51)-\mathrm{La}(1)-\mathrm{O}(4)$ & $128.04(10)$ \\
\hline $\mathrm{O}(232)^{2}-\mathrm{La}(1)-\mathrm{O}(4)$ & $70.92(11)$ \\
\hline $\mathrm{O}(1)-\mathrm{La}(1)-\mathrm{O}(4)$ & $127.56(11)$ \\
\hline $\mathrm{O}(3)-\mathrm{La}(1)-\mathrm{O}(4)$ & $67.81(10)$ \\
\hline $\mathrm{O}(432)-\mathrm{La}(1)-\mathrm{O}(2)$ & $71.88(10)$ \\
\hline $\mathrm{O}(332)^{1}-\mathrm{La}(1)-\mathrm{O}(2)$ & $242.07(10)$ \\
\hline $\mathrm{O}(51)-\mathrm{La}(1)-\mathrm{O}(2)$ & $66.09(10)$ \\
\hline
\end{tabular}




$\begin{array}{lc}\mathrm{O}(232)^{2}-\mathrm{La}(1)-\mathrm{O}(2) & 76.19(10) \\ \mathrm{O}(1)-\mathrm{La}(1)-\mathrm{O}(2) & 69.92(12) \\ \mathrm{O}(3)-\mathrm{La}(1)-\mathrm{O}(2) & 138.14(10) \\ \mathrm{O}(4)-\mathrm{La}(1)-\mathrm{O}(2) & 130.91(10) \\ \mathrm{O}(432)-\mathrm{La}(1)-\mathrm{O}(521) & 133.46(8) \\ \mathrm{O}(332)^{1}-\mathrm{La}(1)-\mathrm{O}(521) & 68.15(8) \\ \mathrm{O}(51)-\mathrm{La}(1)-\mathrm{O}(521) & 61.25(8) \\ \mathrm{O}(232)^{2}-\mathrm{La}(1)-\mathrm{O}(521) & 137.67(9) \\ \mathrm{O}(1)-\mathrm{La}(1)-\mathrm{O}(521) & 68.27(10) \\ \mathrm{O}(3)-\mathrm{La}(1)-\mathrm{O}(521) & 71.52(9) \\ \mathrm{O}(4)-\mathrm{La}(1)-\mathrm{O}(521) & 130.59(9) \\ \mathrm{O}(2)-\mathrm{La}(1)-\mathrm{O}(521) & 98.19(10) \\ \mathrm{C}(332)-\mathrm{O}(332)-\mathrm{La}(1)^{3} & 156.8(3) \\ \mathrm{C}(232)-\mathrm{O}(232)-\mathrm{La}(1)^{4} & 148.2(3) \\ \mathrm{C}(432)-\mathrm{O}(432)-\mathrm{La}(1) & 145.5(2) \\ \mathrm{C}(51)-\mathrm{O}(51)-\mathrm{La}(1) & 145.7(2) \\ \mathrm{N}(52)-\mathrm{O}(521)-\mathrm{La}(1) & 144.6(2)\end{array}$

Symmetry transformations used to generate equivalent atoms:

${ }^{1} \mathrm{x}-1 / 2,-\mathrm{y}+1 / 2, \mathrm{z}-1 / 2 ;{ }^{2} \mathrm{x}, \mathrm{y}, \mathrm{z}-1 ;{ }^{3} \mathrm{x}+1 / 2,-\mathrm{y}+1 / 2, \mathrm{z}+1 / 2 ;{ }^{4} \mathrm{x}, \mathrm{y}, \mathrm{z}+1$ 
Table S7. Hydrogen bonds for LaL [A and $\left.{ }^{\circ}\right]$.

\begin{tabular}{|c|c|c|c|c|}
\hline D-H...A & $\mathrm{d}(\mathrm{D}-\mathrm{H})$ & d(H...A) & $\mathrm{d}(\mathrm{D} \ldots \mathrm{A})$ & $<(\mathrm{DHA})$ \\
\hline $\mathrm{N}(132)-\mathrm{H}(132) \ldots \mathrm{O}(25)$ & 0.88 & 2.16 & $2.963(4)$ & 150.6 \\
\hline $\mathrm{O}(134)-\mathrm{H}(134) \ldots \mathrm{O}(61)$ & $0.833(14)$ & $1.77(2)$ & $2.576(4)$ & $164(5)$ \\
\hline $\mathrm{O}(134)-\mathrm{H}(134) \ldots \mathrm{O}(661)$ & $0.833(14)$ & $2.46(5)$ & $2.953(5)$ & 119(4) \\
\hline $\mathrm{N}(232)-\mathrm{H}(232) \ldots \mathrm{O}(35)$ & 0.88 & 2.19 & $2.974(4)$ & 148.2 \\
\hline $\mathrm{O}(234)-\mathrm{H}(234) \ldots \mathrm{O}(5)$ & 0.84 & 2.27 & $2.901(5)$ & 132.2 \\
\hline $\mathrm{N}(332)-\mathrm{H}(332) \ldots \mathrm{O}(45)$ & 0.88 & 2.36 & $3.116(5)$ & 144.0 \\
\hline $\mathrm{O}(334)-\mathrm{H}(334) \ldots \mathrm{O}(134)^{3}$ & $0.844(14)$ & $2.07(4)$ & $2.716(5)$ & $132(5)$ \\
\hline $\mathrm{N}(432)-\mathrm{H}(432) \ldots \mathrm{O}(43)$ & 0.88 & 2.10 & $2.547(4)$ & 110.7 \\
\hline $\mathrm{O}(434)-\mathrm{H}(434) \ldots \mathrm{O}(561)^{4}$ & 0.84 & 2.36 & $3.074(14)$ & 143.1 \\
\hline $\mathrm{O}(435)-\mathrm{H}(435) \ldots \mathrm{O}(5)^{2}$ & 0.84 & 2.36 & $2.848(11)$ & 117.9 \\
\hline $\mathrm{O}(1)-\mathrm{H}(1 \mathrm{AO}) \ldots \mathrm{O}(334)^{1}$ & $0.849(18)$ & $2.22(3)$ & $2.995(5)$ & $151(4)$ \\
\hline $\mathrm{O}(1)-\mathrm{H}(1 \mathrm{BO}) \ldots \mathrm{O}(71)$ & $0.815(18)$ & $2.01(3)$ & $2.760(5)$ & $153(5)$ \\
\hline $\mathrm{O}(1)-\mathrm{H}(1 \mathrm{BO}) \ldots \mathrm{O}(761)$ & $0.815(18)$ & $2.32(4)$ & $2.924(4)$ & $131(5)$ \\
\hline $\mathrm{O}(2)-\mathrm{H}(2 \mathrm{AO}) \ldots \mathrm{O}(561)$ & $0.820(18)$ & $2.18(2)$ & $2.999(5)$ & $177(5)$ \\
\hline $\mathrm{O}(3)-\mathrm{H}(3 \mathrm{BO}) \ldots \mathrm{O}(621)^{3}$ & $0.819(18)$ & $2.20(3)$ & $2.968(4)$ & $157(4)$ \\
\hline $\mathrm{O}(4)-\mathrm{H}(4 \mathrm{AO}) \ldots \mathrm{O}(132)^{3}$ & $0.841(19)$ & $2.14(3)$ & $2.937(4)$ & $157(5)$ \\
\hline $\mathrm{O}(4)-\mathrm{H}(4 \mathrm{BO}) \ldots \mathrm{O}(5)^{2}$ & $0.847(19)$ & $1.90(3)$ & $2.711(5)$ & $161(5)$ \\
\hline
\end{tabular}

Symmetry transformations used to generate equivalent atoms:

${ }^{1} \mathrm{x}-1 / 2,-\mathrm{y}+1 / 2, \mathrm{z}-1 / 2 ;{ }^{2} \mathrm{x}, \mathrm{y}, \mathrm{z}-1 ;{ }^{3} \mathrm{x}+1 / 2,-\mathrm{y}+1 / 2, \mathrm{z}-1 / 2 ;{ }^{4}-\mathrm{x},-\mathrm{y},-\mathrm{z}$ 


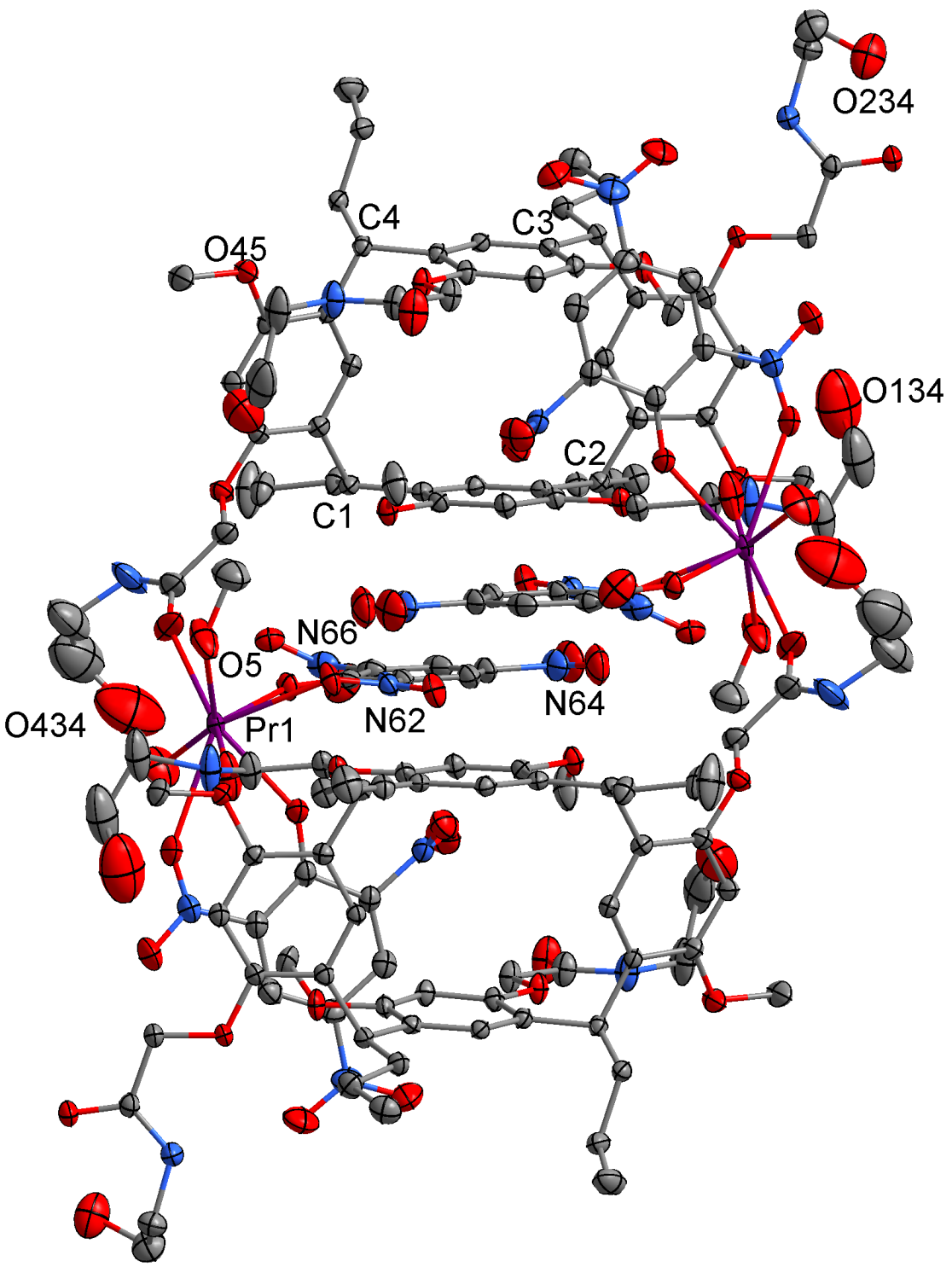

Fig S4 Molecular structure of PrL. Hydrogen atoms and the minor components of the disordered atoms have been omitted. Ellipsoids have been drawn at the 50\% probability level. 
Table S8. Selected bond lengths [Å] and angles $\left[{ }^{\circ}\right]$ for $\operatorname{Pr} \boldsymbol{L}$.

\begin{tabular}{|c|c|}
\hline $\operatorname{Pr}(1)-\mathrm{O}(232)^{1}$ & $2.3872(16)$ \\
\hline $\operatorname{Pr}(1)-\mathrm{O}(432)$ & $2.4050(19)$ \\
\hline $\operatorname{Pr}(1)-\mathrm{O}(61)$ & $2.4192(15)$ \\
\hline $\operatorname{Pr}(1)-\mathrm{O}(51)$ & $2.4226(17)$ \\
\hline $\operatorname{Pr}(1)-\mathrm{O}(132)^{2}$ & $2.4492(19)$ \\
\hline $\operatorname{Pr}(1)-\mathrm{O}(1)$ & $2.493(2)$ \\
\hline $\operatorname{Pr}(1)-\mathrm{O}(5)$ & $2.527(2)$ \\
\hline $\operatorname{Pr}(1)-\mathrm{O}(621)$ & $2.5848(17)$ \\
\hline $\operatorname{Pr}(1)-\mathrm{O}(521)$ & $2.700(2)$ \\
\hline $\mathrm{O}(232)^{1}-\operatorname{Pr}(1)-\mathrm{O}(432)$ & $76.23(6)$ \\
\hline $\mathrm{O}(232)^{1}-\operatorname{Pr}(1)-\mathrm{O}(61)$ & $142.95(6)$ \\
\hline $\mathrm{O}(432)-\operatorname{Pr}(1)-\mathrm{O}(61)$ & $70.97(6)$ \\
\hline $\mathrm{O}(232)^{1}-\operatorname{Pr}(1)-\mathrm{O}(51)$ & $132.90(6)$ \\
\hline $\mathrm{O}(432)-\mathrm{Pr}(1)-\mathrm{O}(51)$ & $142.43(7)$ \\
\hline $\mathrm{O}(61)-\operatorname{Pr}(1)-\mathrm{O}(51)$ & $72.85(6)$ \\
\hline $\mathrm{O}(232)^{1}-\operatorname{Pr}(1)-\mathrm{O}(132)^{2}$ & $80.18(6)$ \\
\hline $\mathrm{O}(432)-\operatorname{Pr}(1)-\mathrm{O}(132)^{2}$ & $139.57(9)$ \\
\hline $\mathrm{O}(61)-\operatorname{Pr}(1)-\mathrm{O}(132)^{2}$ & $136.68(6)$ \\
\hline $\mathrm{O}(51)-\operatorname{Pr}(1)-\mathrm{O}(132)^{2}$ & $76.27(7)$ \\
\hline $\mathrm{O}(232) 1-\operatorname{Pr}(1)-\mathrm{O}(1)$ & $79.29(7)$ \\
\hline $\mathrm{O}(432)-\operatorname{Pr}(1)-\mathrm{O}(1)$ & 76.64(9) \\
\hline $\mathrm{O}(61)-\operatorname{Pr}(1)-\mathrm{O}(1)$ & 76.84(7) \\
\hline $\mathrm{O}(51)-\operatorname{Pr}(1)-\mathrm{O}(1)$ & $85.66(8)$ \\
\hline $\mathrm{O}(132)^{2}-\operatorname{Pr}(1)-\mathrm{O}(1)$ & $130.19(9)$ \\
\hline $\mathrm{O}(232)^{1}-\mathrm{Pr}(1)-\mathrm{O}(5)$ & 72.74(7) \\
\hline $\mathrm{O}(432)-\operatorname{Pr}(1)-\mathrm{O}(5)$ & $72.61(10)$ \\
\hline $\mathrm{O}(61)-\operatorname{Pr}(1)-\mathrm{O}(5)$ & $112.02(7)$ \\
\hline $\mathrm{O}(51)-\operatorname{Pr}(1)-\mathrm{O}(5)$ & $131.96(8)$ \\
\hline $\mathrm{O}(132)^{2}-\operatorname{Pr}(1)-\mathrm{O}(5)$ & $69.24(9)$ \\
\hline $\mathrm{O}(1)-\operatorname{Pr}(1)-\mathrm{O}(5)$ & $142.33(9)$ \\
\hline $\mathrm{O}(232)^{1}-\operatorname{Pr}(1)-\mathrm{O}(621)$ & $140.33(5)$ \\
\hline $\mathrm{O}(432)-\operatorname{Pr}(1)-\mathrm{O}(621)$ & $100.05(7)$ \\
\hline $\mathrm{O}(61)-\operatorname{Pr}(1)-\mathrm{O}(621)$ & $64.04(5)$ \\
\hline $\mathrm{O}(51)-\mathrm{Pr}(1)-\mathrm{O}(621)$ & $72.45(6)$ \\
\hline $\mathrm{O}(132)^{2}-\operatorname{Pr}(1)-\mathrm{O}(621)$ & $78.19(6)$ \\
\hline
\end{tabular}




$\begin{array}{lr}\mathrm{O}(1)-\operatorname{Pr}(1)-\mathrm{O}(621) & 139.15(7) \\ \mathrm{O}(5)-\operatorname{Pr}(1)-\mathrm{O}(621) & 68.62(6) \\ \mathrm{O}(232)^{1}-\operatorname{Pr}(1)-\mathrm{O}(521) & 69.59(6) \\ \mathrm{O}(432)-\operatorname{Pr}(1)-\mathrm{O}(521) & 132.03(8) \\ \mathrm{O}(61)-\operatorname{Pr}(1)-\mathrm{O}(521) & 122.70(6) \\ \mathrm{O}(51)-\operatorname{Pr}(1)-\mathrm{O}(521) & 63.61(6) \\ \mathrm{O}(132)^{2}-\operatorname{Pr}(1)-\mathrm{O}(521) & 65.45(8) \\ \mathrm{O}(1)-\operatorname{Pr}(1)-\mathrm{O}(521) & 64.92(8) \\ \mathrm{O}(5)-\operatorname{Pr}(1)-\mathrm{O}(521) & 124.52(8) \\ \mathrm{O}(621)-\operatorname{Pr}(1)-\mathrm{O}(521) & 127.73(6)\end{array}$

Symmetry transformations used to generate equivalent atoms:

${ }^{1} \mathrm{x}+1, \mathrm{y}+1, \mathrm{z} ; \quad{ }^{2} 1-\mathrm{x}, 2-\mathrm{y}, 2-\mathrm{z}$ 
Table S9. Hydrogen bonds for $\operatorname{Pr} \boldsymbol{L}\left[A\right.$ and $\left.^{\circ}\right]$.

\begin{tabular}{lcccc}
\hline $\mathrm{D}-\mathrm{H} \ldots \mathrm{A}$ & $\mathrm{d}(\mathrm{D}-\mathrm{H})$ & $\mathrm{d}(\mathrm{H} \ldots \mathrm{A})$ & $\mathrm{d}(\mathrm{D} \ldots \mathrm{A})$ & $<(\mathrm{DHA})$ \\
\hline $\mathrm{N}(132)-\mathrm{H}(132) \ldots \mathrm{O}(25)$ & 0.88 & 2.24 & $3.046(3)$ & 152.3 \\
$\mathrm{~N}(232)-\mathrm{H}(232) \ldots \mathrm{O}(6)$ & 0.88 & 2.11 & $2.818(3)$ & 136.4 \\
$\mathrm{O}(234)-\mathrm{H}(234) \ldots \mathrm{O}(332)^{3}$ & 0.84 & 1.89 & $2.722(3)$ & 170.3 \\
$\mathrm{C}(251)-\mathrm{H}(25 \mathrm{C}) \ldots \mathrm{O}(522)^{2}$ & 0.98 & 2.59 & $3.521(4)$ & 158.3 \\
$\mathrm{~N}(332)-\mathrm{H}(332) \ldots \mathrm{O}(45)$ & 0.88 & 2.55 & $3.356(3)$ & 152.3 \\
$\mathrm{O}(334)-\mathrm{H}(334) \ldots \mathrm{O}(741)$ & 0.84 & 2.32 & $3.038(10)$ & 143.4 \\
$\mathrm{O}(334)-\mathrm{H}(334) \ldots \mathrm{O}(861)$ & 0.84 & 2.51 & $3.21(3)$ & 142.2 \\
$\mathrm{O}(334)-\mathrm{H}(334) \ldots \mathrm{O}(862)$ & 0.84 & 2.51 & $3.331(9)$ & 165.3 \\
$\mathrm{O}(334)-\mathrm{H}(334) \ldots \mathrm{O}(2)$ & 0.84 & 2.59 & $3.204(12)$ & 130.7 \\
$\mathrm{~N}(432)-\mathrm{H}(432) \ldots \mathrm{O}(722)$ & 0.88 & 2.27 & $3.049(7)$ & 146.8 \\
$\mathrm{~N}(435)-\mathrm{H}(43 \mathrm{H}) \ldots \mathrm{O}(437)$ & 0.88 & 2.30 & $2.72(3)$ & 109.4 \\
$\mathrm{O}(5)-\mathrm{H}(5 \mathrm{O}) \ldots \mathrm{O}(234)^{1}$ & 0.95 & 2.06 & $2.736(3)$ & 126.3 \\
$\mathrm{O}(6)-\mathrm{H}(6 \mathrm{O}) \ldots \mathrm{O}(71)^{4}$ & 0.84 & 1.72 & $2.556(5)$ & 171.8 \\
$\mathrm{O}(6)-\mathrm{H}(6 \mathrm{O}) \ldots \mathrm{O}(822)^{4}$ & 0.84 & 2.57 & $3.287(15)$ & 143.8 \\
$\mathrm{O}(7)-\mathrm{H}(7) \ldots \mathrm{O}(841)$ & 0.84 & 2.53 & $3.09(2)$ & 124.3 \\
$\mathrm{O}(7)-\mathrm{H}(7) \ldots \mathrm{O}(842)$ & 0.84 & 2.02 & $2.818(16)$ & 158.4 \\
$\mathrm{O}(7)-\mathrm{H}(7) \ldots \mathrm{O}(8)^{5}$ & 0.84 & 1.86 & $2.651(8)$ & 157.4 \\
& & & & \\
\hline
\end{tabular}

Symmetry transformations used to generate equivalent atoms:

${ }^{1} \mathrm{x}+1, \mathrm{y}+1, \mathrm{z} ; \quad{ }^{2} \mathrm{x}-1, \mathrm{y}-1, \mathrm{z} ;{ }^{3} 1-\mathrm{x}, 1-\mathrm{y}, 2-\mathrm{z} ;{ }^{4} 1$ 1-x,1-y,1-z; ${ }^{5} 2-\mathrm{x}, 2-\mathrm{y}, 1-\mathrm{z}$ 
Additional details for the structure of $\mathrm{YbL}$

Table S10. Selected bond lengths $[\AA]$ and angles $\left[{ }^{\circ}\right]$ for $Y b \boldsymbol{L}$.

\begin{tabular}{|c|c|}
\hline $\mathrm{Yb}(1)-\mathrm{O}(71)$ & $2.20(5)$ \\
\hline $\mathrm{Yb}(1)-\mathrm{O}(61)$ & $2.230(6)$ \\
\hline $\mathrm{Yb}(1)-\mathrm{O}(232)^{1}$ & $2.236(5)$ \\
\hline $\mathrm{Yb}(1)-\mathrm{O}(432)$ & $2.256(6)$ \\
\hline $\mathrm{Yb}(1)-\mathrm{O}(132)^{2}$ & $2.257(6)$ \\
\hline $\mathrm{Yb}(1)-\mathrm{O}(1)$ & $2.275(7)$ \\
\hline $\mathrm{Yb}(1)-\mathrm{O}(81)$ & $2.32(5)$ \\
\hline $\mathrm{Yb}(1)-\mathrm{O}(721)$ & $2.38(2)$ \\
\hline $\mathrm{Yb}(1)-\mathrm{O}(661)$ & $2.497(6)$ \\
\hline $\mathrm{Yb}(1)-\mathrm{O}(821)$ & $2.52(2)$ \\
\hline $\mathrm{O}(71)-\mathrm{Yb}(1)-\mathrm{O}(61)$ & $81.6(13)$ \\
\hline $\mathrm{O}(71)-\mathrm{Yb}(1)-\mathrm{O}(232)^{1}$ & $107.9(16)$ \\
\hline $\mathrm{O}(61)-\mathrm{Yb}(1)-\mathrm{O}(232)^{1}$ & $143.9(2)$ \\
\hline $\mathrm{O}(71)-\mathrm{Yb}(1)-\mathrm{O}(432)$ & $141.5(11)$ \\
\hline $\mathrm{O}(61)-\mathrm{Yb}(1)-\mathrm{O}(432)$ & $73.9(2)$ \\
\hline $\mathrm{O}(232)^{1}-\mathrm{Yb}(1)-\mathrm{O}(432)$ & $78.2(2)$ \\
\hline $\mathrm{O}(71)-\mathrm{Yb}(1)-\mathrm{O}(132) 2$ & $73.5(11)$ \\
\hline $\mathrm{O}(61)-\mathrm{Yb}(1)-\mathrm{O}(132) 2$ & $137.3(2)$ \\
\hline $\mathrm{O}(232)^{1}-\mathrm{Yb}(1)-\mathrm{O}(132)^{2}$ & $77.9(2)$ \\
\hline $\mathrm{O}(432)-\mathrm{Yb}(1)-\mathrm{O}(132)^{2}$ & $142.9(3)$ \\
\hline $\mathrm{O}(71)-\mathrm{Yb}(1)-\mathrm{O}(1)$ & $139.5(13)$ \\
\hline $\mathrm{O}(61)-\mathrm{Yb}(1)-\mathrm{O}(1)$ & $105.6(3)$ \\
\hline $\mathrm{O}(232)^{1}-\mathrm{Yb}(1)-\mathrm{O}(1)$ & $89.7(3)$ \\
\hline $\mathrm{O}(432)-\mathrm{Yb}(1)-\mathrm{O}(1)$ & $76.8(2)$ \\
\hline $\mathrm{O}(132)^{2}-\mathrm{Yb}(1)-\mathrm{O}(1)$ & $75.1(3)$ \\
\hline $\mathrm{O}(61)-\mathrm{Yb}(1)-\mathrm{O}(81)$ & $76.6(13)$ \\
\hline $\mathrm{O}(232)^{1}-\mathrm{Yb}(1)-\mathrm{O}(81)$ & $109.9(15)$ \\
\hline $\mathrm{O}(432)-\mathrm{Yb}(1)-\mathrm{O}(81)$ & $135.7(11)$ \\
\hline $\mathrm{O}(132)^{2}-\mathrm{Yb}(1)-\mathrm{O}(81)$ & $79.5(11)$ \\
\hline $\mathrm{O}(1)-\mathrm{Yb}(1)-\mathrm{O}(81)$ & $143.7(13)$ \\
\hline $\mathrm{O}(71)-\mathrm{Yb}(1)-\mathrm{O}(721)$ & $67.4(15)$ \\
\hline $\mathrm{O}(61)-\mathrm{Yb}(1)-\mathrm{O}(721)$ & $79.7(6)$ \\
\hline $\mathrm{O}(232)^{1}-\mathrm{Yb}(1)-\mathrm{O}(721)$ & $72.8(6)$ \\
\hline
\end{tabular}




$\begin{array}{lc}\mathrm{O}(432)-\mathrm{Yb}(1)-\mathrm{O}(721) & 79.1(6) \\ \mathrm{O}(132)^{2}-\mathrm{Yb}(1)-\mathrm{O}(721) & 119.6(6) \\ \mathrm{O}(1)-\mathrm{Yb}(1)-\mathrm{O}(721) & 152.7(6) \\ \mathrm{O}(71)-\mathrm{Yb}(1)-\mathrm{O}(661) & 75.8(16) \\ \mathrm{O}(61)-\mathrm{Yb}(1)-\mathrm{O}(661) & 67.2(2) \\ \mathrm{O}(232)^{1}-\mathrm{Yb}(1)-\mathrm{O}(661) & 148.5(2) \\ \mathrm{O}(432)-\mathrm{Yb}(1)-\mathrm{O}(661) & 119.1(2) \\ \mathrm{O}(132)^{2}-\mathrm{Yb}(1)-\mathrm{O}(661) & 73.3(2) \\ \mathrm{O}(1)-\mathrm{Yb}(1)-\mathrm{O}(661) & 71.0(2) \\ \mathrm{O}(81)-\mathrm{Yb}(1)-\mathrm{O}(661) & 77.1(15) \\ \mathrm{O}(721)-\mathrm{Yb}(1)-\mathrm{O}(661) & 133.3(6) \\ \mathrm{O}(61)-\mathrm{Yb}(1)-\mathrm{O}(821) & 72.9(6) \\ \mathrm{O}(232)^{1}-\mathrm{Yb}(1)-\mathrm{O}(821) & 76.9(6) \\ \mathrm{O}(432)-\mathrm{Yb}(1)-\mathrm{O}(821) & 72.0(5) \\ \mathrm{O}(132)^{2}-\mathrm{Yb}(1)-\mathrm{O}(821) & 128.4(5) \\ \mathrm{O}(1)-\mathrm{Yb}(1)-\mathrm{O}(821) & 147.9(6) \\ \mathrm{O}(81)-\mathrm{Yb}(1)-\mathrm{O}(821) & 68.1(14) \\ \mathrm{O}(661)-\mathrm{Yb}(1)-\mathrm{O}(821) & 131.8(6)\end{array}$

Symmetry transformations used to generate equivalent atoms:

${ }^{1} \mathrm{x}, \mathrm{y}-1, \mathrm{z} ;{ }^{2} 1-\mathrm{x}, 1-\mathrm{y}, 1-\mathrm{z}$

${ }^{1}$ Sheldrick, G.M. (2015). Acta Cryst. C71, 3-8 